\title{
Some remarks on the earthquakes of Fennoscandia: A conceptual seismological model drawn from the perspective of hyperextension
}

\section{Thomas FitzMaurice Redfield \& Per Terje Osmundsen}

Redfield, T.F. \& Osmundsen, P.T.: Some remarks on the earthquakes of Fennoscandia: A conceptual seismological model drawn from the perspectives of hyperextension. Norwegian Journal of Geology, Vol 94, pp. 233-262. Trondheim 2015, ISSN 029-196X.

To a first order, patterns of Fennoscandia's seismicity reflect the benchmark domain boundaries of its Mesozoic rifted margin. Three distinct belts of earthquakes strike sub-parallel to the generalized line of breakup. The outermost seismic belt (SB1) marks the Taper Break (TB), or the zone of flexural coupling/decoupling between the distal (seaward) and proximal/necking (landward) domains. A coastal belt (SB2) follows the Innermost Limit of Extension, defined as the onset of $39 \mathrm{~km}$-thick crystalline continental crust. An interior belt (SB3) follows the Hinterland Break in Slope, or the landward limit of the Scandinavian rifted margin. Between each belt, large portions of the necking, proximal, and hinterland domains are seismically quiescent. Evaluation of the 'Cumulative Seismic Moment' $\left(\mathrm{CSM}_{\mathrm{w}}\right)$ per unit area indicates that the release of seismic energy is asymmetric. Although some of Fennoscandia's largest seismic events occur in the dominantly Proterozoic to Archean lithosphere of the eastern craton, $80 \%$ of Fennoscandian $\mathrm{CSM}_{\mathrm{w}}$ maps to the domain boundaries of the western rifted margin. $\mathrm{CSM}_{\mathrm{w}}$ energy tends to be highest at the TB and decreases systematically towards the continental interior.

As proposed by many previous studies, a first-order spatial correlation between Scandinavia's offshore earthquake belt and voluminous, geologically rapid, sedimentary loading during the Neogene period is evident. However, the presence of thinned, faulted crystalline basement is also a very important factor behind Scandinavia's offshore seismicity. Where the Neogene deposits are at their thickest the underlying crust is dominantly oceanic; $\mathrm{CSM}_{\mathrm{w}}$ is lower per unit area there than where lesser Plio-Pleistocene loading impacts continental crust that was fully prepared by Mesozoic necking and hyperextension. $\mathrm{CSM}_{\mathrm{w}}$ data suggest that the 'strength' of the TB and the continental margin's distal domain is significantly less than that of relatively young (ca. $54 \mathrm{Ma}$ ) oceanic lithosphere. Our data imply that ridge push does not contribute significantly to Fennoscandia's seismicity. Rather, we find that thin-plate bending stresses stemming from offshore depositional loading conspire with unbuttressed Gravitational Potential Energy (GPE), onshore erosion, and post-glacial isostatic rebound to generate Fennoscandia’s earthquakes.

We present a conceptual seismological model for Fennoscadia that is consistent with modern hypotheses of extended margin evolution, including post-breakup reactivation by footwall uplift in regions adjacent to sharp crustal taper. Illustrated by simple concepts of elastic thin-plate theory, the model honors our conclusion that Fennoscandian seismicity is principally the product of locally derived stress fields and that far field stress from the oceanic domain is unlikely to penetrate deeply into a hyperextended continental margin. It predicts the locations of the observed seismic belts and seismic gaps with the mathematics of thin-plate bending. It describes how the outer seismic belt will remain localized in the vicinity of the TB in response to the permanently contrasting material properties and flexural rigidities of the distal and necking/proximal domains. It suggests that overprinting stress may sweep across the proximal domain and magma-stiffened portions of the distal domains as post-thinning cooling progressively increases both the effective lithospheric rigidity and its associated flexural wavelength. Our model is built from concepts and data presented by previous authors in many earlier studies, and is at least partly applicable to other post-breakup rifted margins.

T.F. Redfield, Geological Survey of Norway, 7491 Trondheim, Norway. P.T. Osmundsen, Geological Survey of Norway, 7491 Trondheim, Norway. Department of Arctic Geology, University Center in Svalbard, 9171 Longyearbyen, Norway.

E-mail corresponding author (T.F. Redfield): tim.redfield@ngu.no

Published online: 15. March, 2015.

This work is licensed under a Creative Commons Attribution 4.0 International License.

\section{Exordium}

A close correspondence between earthquakes and platetectonic boundary zones is generally accepted (e.g., Tarr et al., 2010). However, stable continental regions can also be on the receiving end of large-magnitude tremors (e.g., Johnston \& Kanter, 1990). Although maps covering stable continental areas commonly exhibit clusters of epicenters, the cause of stress build-up and release is not readily linked to individual structures or discrete tectonic processes (op. cit.). Fennoscandia provides no exception; widespread, relatively low-magnitude, not-well-explained earthquakes characterize all of the continental Nordic countries (Fig. 1).

Because greater than $90 \%$ of Fennoscandia's $M_{w} \geq$ 2.0 earthquake epicenters occur more than $500 \mathrm{~km}$ from either the Mid-Atlantic spreading ridge or the 


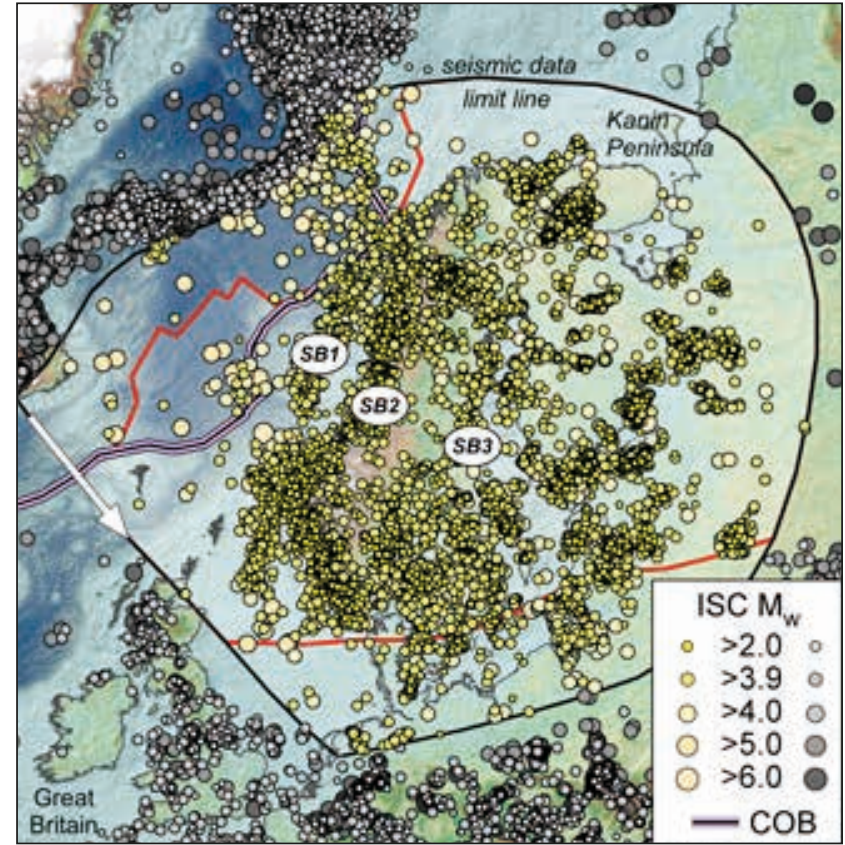

Figure 1. Map showing Fennoscandian and North Atlantic seismicity. Circles represent epicenters archived by the International Seismological Center (ISC) between 1960 and 2012, scaled by magnitude $\left(M_{w}=2.0\right.$ minimum cutoff). Yellow circles represent events considered to lie within the seismic limits of Fennoscandia and its oceanic domain (see text). Excepting the Mid-Atlantic spreading center, the outer polygon border is surrounded by a zone of few to extremely few earthquakes. Lightest white (outer) polygon (black border; 8981 epicenters) represents the limit of the seismic dataset discussed in this paper. Darker white (inner) polygon (red border; 8581 epicenters) contains events more than 500 $\mathrm{km}$ in liner distance from the Mid-Atlantic spreading ridge or the European Alpine front. White arrow symbolizes the generalized North Atlantic plate-tectonic flow line (see Mosar et al., 2002). Note that the raw ISC catalogue does not filter against anthropogenic events such as construction-related explosions. For the rest of this paper we will use the Finnish Institute for Seismology at the University of Helsinki FENCAT catalogue (e.g., Ahjos \& Uski, 1992) which we consider to more closely represent the natural state of seismicity of Fennoscandia. SB1, SB2 and SB3 denote seismic belts discussed in the text.

Alpine-Africa collision front (Fig. 1), the majority cannot be directly ascribed to plate boundary deformation. Stress from continental deglaciation is considered capable of producing post-breakup rifted margin and intracontinental earthquakes (e.g., Arvidsson, 1996; Wu \& Hasagawa, 1996). Gudmundsson (1999) consequently suggested that many, if not most, of Scandinavia's earthquakes can be well explained by post-glacial rebound. However, Bungum et al. (2010) concluded "The dominant driving forces range from plate-related (such as ridge push) through regional to local ones (such as topography); all, however, are somehow related to lateral inhomogeneities in lithospheric structure [...and...] It will take more work to separate these potential driving forces."

Inspired by the exhortation, we feel a bit more remains to be said concerning Fennoscandian earthquakes. This is particularly so in the light of current concepts of how extended margins evolve. Other newly reinterpreted, non-glaciated, hyperextended margins such as Southeast Brasil also display seismicity in association with onshore escarpments and offshore sedimentary basins (Riccomini et al., 1989; Assumpção, 1992, 1998; Assumpção et al., 1997, 2011; Riccomini \& Assumpção, 1999; Bezerra \& Vita-Finzi, 2000; Bezerra et al., 2008, 2014). In this paper we focus on how patterns of Scandinavian seismicity can be interpreted within the context of a specific geologic model that describes the evolution of the Scandinavian rifted margin from Mesozoic extension to the present-day. We expand our conclusions to a conceptual model that may partly apply to other of the Earth's rifted margins.

In describing today's margins we use the term 'rifted' in lieu of 'passive' in order to emphasize two important points. Firstly, post-breakup time can be characterized by significant faulting, including $\mathrm{km}$-scale footwall uplift of the proximal margin domain (see Discussion, below). Secondly, the extended margin life cycle does not end with oceanization and breakup. Its evolution continues, following a trajectory that was predetermined by the style of extension that shaped its proximal and necking domains. In addition to the five margin phases described by Péron-Pinvidic et al. (2013; see The extended margin, below), Redfield \& Osmundsen (2013) suggested that an accommodation phase is warranted. Commencing perhaps as early as sag basin time and continuing today, it is probably driven by mass transfer from the escarpment to the basins offshore. The accommodation phase is independent of external factors such as mantle convection, lithospheric composition or delamination, glacial history, magmatic style, or far-field forces such as those modeled from ridge push or changes in plate motion. As shown in this paper, accommodation phase footwall uplift of the inner proximal domain can be linked to the present-day seismicity of the Fennoscandian rifted margin.

\section{The extended margin}

Because Fennoscandia's Atlantic margin underwent several episodes of severe, post-Caledonian thinning prior to the Early Cenozoic onset of sea-floor spreading, modern concepts of how continents break apart are pertinent. Many extended margins can be divided into a suite of five domains (Fig. 2) that are discrete in both their time of formation and the process by which they form (e.g., Péron-Pinvidic et al., 2013). These are (1) the proximal domain (fault-controlled rift basins formed under ductile/ brittle extension during the stretching phase), (2) the necking domain (severe thinning of continental crust from ca. $30 \mathrm{~km}$ to ca. $10 \mathrm{~km}$, formed during the thinning phase), 3) the distal domain (complete crustal embrittlement, penetrative faulting, and potentially mantle exhumation, formed during the hyperextension-exhumation phase), and 4) the outer domain (a continent-to-ocean transition comprised by basement of uncertain composition culminating in a Continent-Ocean Boundary (COB) zone, formed during the magmatic phase). The fifth is 


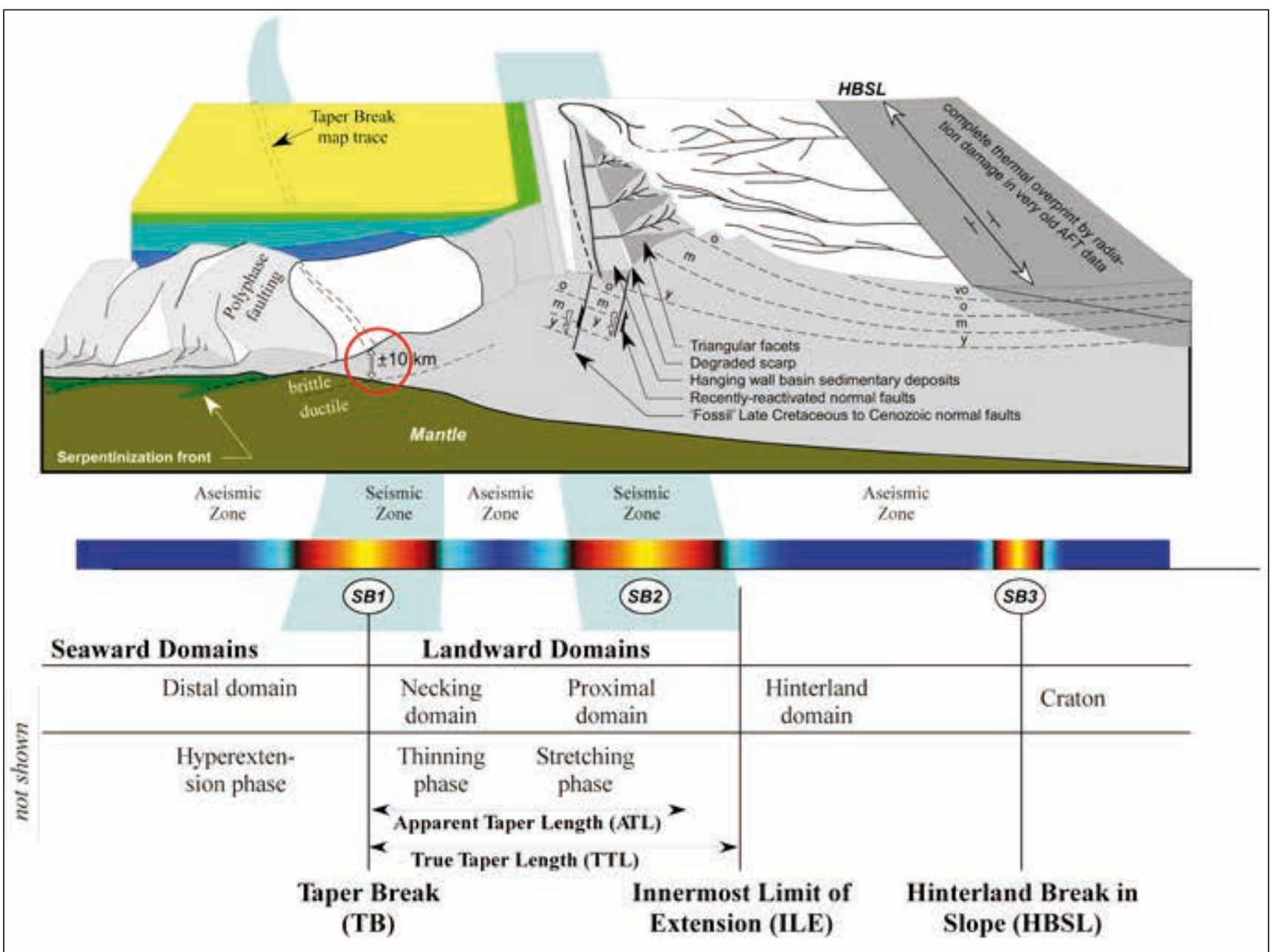

Figure 2. Cartoon modified from Redfield et al. (2005a, b), Osmundsen \& Ebbing (2008), Redfield \& Osmundsen (2013) and Osmundsen (unpublished) defining the terminology used in this paper. Domain and phase definitions follow Péron-Pinvidic et al. (2013; see main text). The landward domains are composed of continental crust affected by stretching-phase and thinning-phase deformation whereas the continental crust of the seaward domains was affected by hyperextension and possibly exhumation-phase deformation (not shown). The Taper Break (TB; red circle) marks the conceptual point of total crustal embrittlement during extension, and conceptually forms the boundary between the landward and seaward domains. We define the True Taper Length (TTL) to be the absolute width of the landward (proximal plus necking) domains, measured from the TB to the point where the crystalline continental crust has not undergone margin-related extension (Innermost Limit of Extension, or ILE). Commonly, the TTL can be approximated by the Apparent Taper Length (ATL), which is the distance between the TB and the escarpment crest (see text). To landward of the proximal margin lies the hinterland. The hinterland was, and remains, deformed by footwall uplift and marginrelated, long-wavelength, lithospheric-scale flexure controlled on the seaward end by the TB. The Hinterland Break in Slope (HBSL) marks the landward edge of the hinterland, and thus the rifted margin. At some point in time, all of the extended margin domains as well as the hinterland have undergone post-thinning phase vertical deformation. Note that very, very old cratonic Apatite Fission Track (AFT) data (darkly shaded area) can be completely overprinted by radiation-enhanced annealing (Hendriks \& Redfield, 2005, 2006). Hot-to-cold scale bar at bottom schematically indicates Cumulative Seismic Moment energy (CSM $M_{w}$ see main text and Fig. 15). Letters $y, m, o$, and vo refer to young, moderate, old, and very old AFT apparent ages. SB1, SB2 and SB3 denote seismic belts discussed in the text.

the oceanic domain itself. Characterized by conveyor-belt, Penrose-type crust (see Conference Participants, 1972; Dilek, 2003), it forms during the final oceanization phase. These domains can be envisioned as elemental building blocks of a generic extended margin (Péron-Pinvidic et al., 2013). Although initially developed for the magma-poor Iberian margin, at least some of these concepts may also be applicable to magma-rich sectors (see Péron-Pinvidic et al., 2013 and Lundin et al., 2014).

An important and unifying concept is that, following extreme thinning, the brittle-ductile transition may migrate to a position below the petrologic Moho (PérezGussinyé \& Reston, 2001). Total embrittlement of the continental crystalline crust can occur if its thickness becomes less than a certain value, commonly cited as ca. $10 \mathrm{~km}$ (op. cit.). Under such circumstances, very large detachment faults can cut through the entire crust and sole in the mantle. Rocks of the lithospheric mantle themselves can then be faulted and potentially serpentinized (Manatschal et al., 2001; Pérez-Gussinyé \& Reston, 2001; Manatschal, 2004; Péron-Pinvidic \& Manatschal, 2009; Zalán et al., 2011; Péron-Pinvidic et al., 2013). Although post-thinning cooling is widely considered to generally 
increase lithospheric strength (e.g., Kusznir \& Park, 1987; Ziegler \& Cloetingh, 2004), the mechanical damage of penetrative faulting and the rheological transformation of olivine to serpentine cannot be healed by loss of heat or the simple passage of time. Consequently, much of the distal domain can potentially comprise a permanently weakened zone (Masson et al., 1994; Faccenna et al., 1999; Péron-Pinvidic et al., 2008, 2013; Mohn et al., 2010; Lundin \& Doré, 2011; Sutra \& Manatschal, 2012; Redfield \& Osmundsen, 2013; this paper).

\section{The landward domains}

From the above it is apparent that the seaward and landward margin domains may exhibit very different bulk rheological properties. The boundary between these zones (Fig. 2) is one of the key architectural parameters of the extended margin. Osmundsen \& Redfield (2011) defined the Taper Break (TB) to be the first landward point where the crustal thickness is reduced to $10 \mathrm{~km}$ or less. This definition assumes that the $10 \mathrm{~km}$ crustal thickness contour closely approximates the point of complete crustal embrittlement during extension (Pérez-Gussinyé \& Reston, 2001) and therefore effectively delimits the boundary between what were the coupled and decoupled domains. As suggested above, the TB may also mark the landward boundary of a zone of permanently weakened lithosphere separating the continent from the ocean. As such, it is also important from the perspective of flexure.

As the crustal wedge thickens landwards, the submerged portion of the proximal domain may blend seamlessly with that which emerges. This raises the question of where it should end. Certain geologic studies have suggested that extended margin escarpments tend to stabilize with time rather than continue to retreat inland (Matmon et al., 2002; Gunnell \& Harbor, 2010). Osmundsen \& Redfield (2011) considered the inland boundary of the extended margin to be marked by the onset of unstretched crystalline crust. This can be approximated by a thickness of $\sim 39 \pm 3 \mathrm{~km}$, a figure derived from the emergent, non-orogenic realm of the CRUST2 (Bassin et al., 2000) model (see Redfield \& Osmundsen, 2013). Several geophysical studies (Kinck et al., 1993; Svenningsen et al., 2007; Stratford et al., 2009; Ebbing et al., 2012) which focussed on imaging the Moho indicate that in Scandinavia the $39 \mathrm{~km}$ crustal thickness contour closely tracks both the escarpment and the conceptual Innermost Boundary Fault system of Mosar (2003). The generalized location of the seaward-facing escarpment crest can thus be considered an easily identified proxy for the Innermost Limit of Extension (ILE; see Fig. 2).

The WNW-verging asymmetry of Scandinavia's topographic envelope is well known (Holtedahl, 1953; Redfield et al., 2005a). Less well known is that a pronounced 'Hinterland Break in Slope (HBSL; see Fig. 2) adjacent to the Gulf of Bothnia can be mapped quantitatively for more than $1000 \mathrm{~km}$. Redfield \& Osmundsen (2013) suggested that because the entire hinterland was uplifted (e.g., Riis,
1996; Lidmar-Bergström, 1999) at some point following severe Mesozoic crustal thinning and subsequent cooling and subsidence, the HBSL effectively marks the landward limit of the Scandinavian rifted margin.

\section{The Taper Hypothesis}

The 'Taper Hypothesis' (Osmundsen \& Redfield, 2011) states that on a given orthogonally hyperextended, rifted margin sector, the 2D length of the tapering crustal wedge (True Taper Length, or TTL; see Fig 2) is inversely proportional to the height of the onshore escarpment. This scaling relationship was initially documented from 40 previously published geoseismic interpretations of rifted margins from six continents (op. cit.). However, Scandinavia's offshore margin structure is well imaged by regional studies (e.g., Raum et al., 2002; Mjelde et al., 2003; Ebbing et al., 2006; Faleide et al., 2008; Osmundsen \& Ebbing, 2008; Ebbing \& Olesen, 2010; Reynisson, 2010; Breivik et al., 2011; Péron-Pinvidic et al., 2013; Kvarven et al., 2014). Although less constrained, the onshore deep crustal structure is sufficiently known that maps of derivative properties such as the effective elastic thickness $\left(\mathrm{T}_{\mathrm{e}}\right.$ ) have been constructed (Poudjom Djomani et al., 1999; Pérez-Gussinyé \& Watts, 2005). These data enabled Redfield \& Osmundsen (2013) to test their Taper Hypothesis under high-definition conditions.

Redfield \& Osmundsen (2013) remapped the Scandinavian TB by interrogating a potential-fieldderived, refraction-controlled crustal thickness grid (Ebbing \& Olesen, 2010; Reynisson, 2010) for the $10 \mathrm{~km}$ crustal thickness contour. They compared the Apparent Taper Length (ATL; see Fig. 2) to the Scandinavian onshore topographic envelope along 234 profiles oriented parallel to the direction of tectonic transport and confirmed the correlation between crustal thinning and rifted margin escarpment elevation for Scandinavia. They also documented the geometric relationships between crustal taper and hinterland river drainages, proximal domain brittle fault fabrics, and juxtaposed landscapes that are predicted by the simple principles of tectonic geomorphology (e.g., Leeder \& Gawthorpe, 1987; Leeder \& Jackson, 1993; Gawthorpe \& Leeder, 2000; Burbank \& Anderson, 2001; Densmore et al., 2004). Redfield \& Osmundsen (2013) suggested that footwall uplift, driven by erosion and deposition and governed by the thinning gradient, was responsible for much of Scandinavia’s Cenozoic topographic rejuvenation.

\section{Some new results}

The grids cited by Redfield \& Osmundsen (2013) were not controlled by the velocity models of Breivik et al. (2011) or Kvarven et al. (2014). As part of this contribution we further refined the Scandinavian TB using their newly presented refraction data (op. cit.) supplemented by comparison with map patterns derived from newly presented gravity data (Andersen et al., 2010). Our 


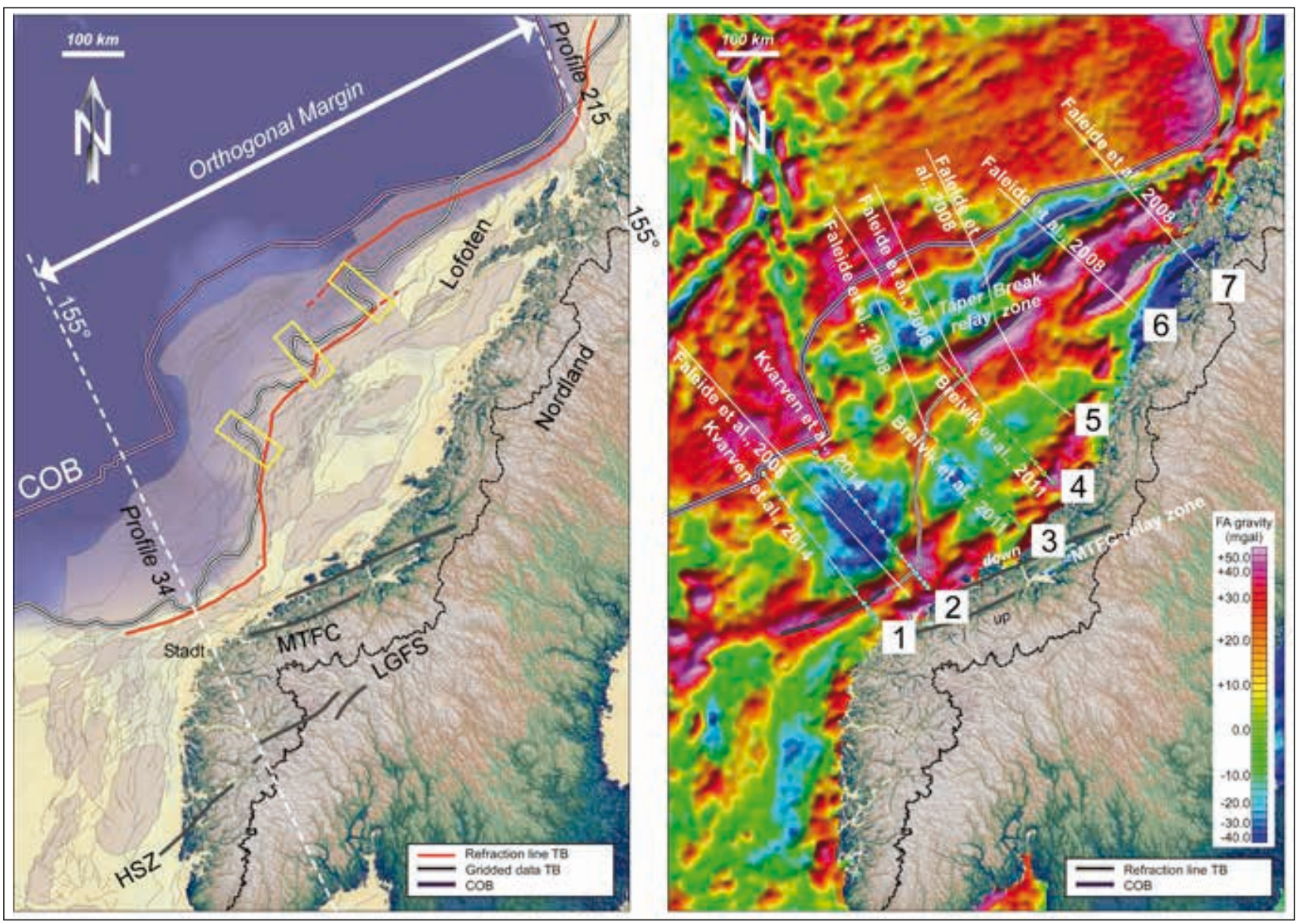

Figure 3. Map (left) showing the difference between the Taper Break (TB) as mapped by gridded data (white highway symbol) and as constrained by newly published, deep seismic refraction data (thick red line). Dashed white lines of azimuth $155^{\circ}$ bracket the ca. $1000 \mathrm{~km}$-long orthogonally stretched sector of the rifted margin, and are parallel to the 234 profiles of Redfield \& Osmundsen (2013). The 2D length of the tapering crustal wedge is measured parallel to the dashed white lines. Within the orthogonally-stretched sectors, offsets between the two different versions of the TB are never greater than $70 \mathrm{~km}$. Major basins from the Norwegian Petroleum Directorate structural element map (Blystad et al., 1995) are shown in mildly transparent ArcGIS Precambrian1 (kind-of-sand-like) color. Note the affinity of the TB for continuous, deep basins. Yellow rectangles call attention to places where the grid-based TB makes a sharp change in azimuth, a function of its nature as a continuous contour. Our new refraction-based TB follows prominent free air gravity anomalies (map at right; gravity data from Andersen et al., 2010). Marine OBS station points are shown as green or cyan circles. Boxed numbers refer to geoseismic refraction profiles shown in Fig. 4. Note the proximity of the MTFC onshore fault tip relay (see Redfield et al., 2005a) to the apparent relay zone between the new refraction-based TB. HSZ - Hardangerfjord Shear Zone, LGFS - Lordal-Gjende Fault System, MTFC - Møre-Trøndelag Fault Complex. The black line represents the drainage divide/ topographic crest and approximates the escarpment crest.

updated TB (Fig. 3) is tied to crustal thicknesses measured from published refraction profiles in 8 locations (Figs. 3 , 4). In between tie points its trace follows prominent positive or negative free air gravity anomalies (Smith \& Sandwell, 1997; Andersen et al., 2010; Fig. 3).

Our new mapping defined two overlapping TB segments that together appear to form an offshore, crustal-scale mega-relay geometry (Fig. 3). Each segment closely tracks the generalized structural elements of the Norwegian margin as mapped by the Norwegian Petroleum Directorate (Blystad et al. 1995). Although the difference is never greater than $70 \mathrm{~km}$, our new refraction-based TB is consistently offset from the 2013 potential field TB (Fig. 3). The greatest discrepancies occur where our 2013 TB turned sharply seaward in order to track the grid-derived (e.g., continuous) crustal thickness contour. These deviations occur in the offshore zone of transition between the Møre-Trøndelag Fault Complex (MTFC) and the Nordland-Lofoten onshore domains, where Redfield et al. (2005a) postulated the existence of a mega-relay geometry onshore (Fig. 3).

We repeated our 2013 ATL (Fig. 2) vs. escarpment elevation analysis using the same 234 closely spaced topographic profiles and our newest refraction-based TB map. The anti-correlation between the topographic envelope maximum and the ATL became stronger (Fig. 5). In the Nordland-Lofoten sector, scaling between ATL and escarpment elevation improved significantly. Spatial analysis shows that the poorest fits to the scaling equation occur in the region of overlap between the outer and the 


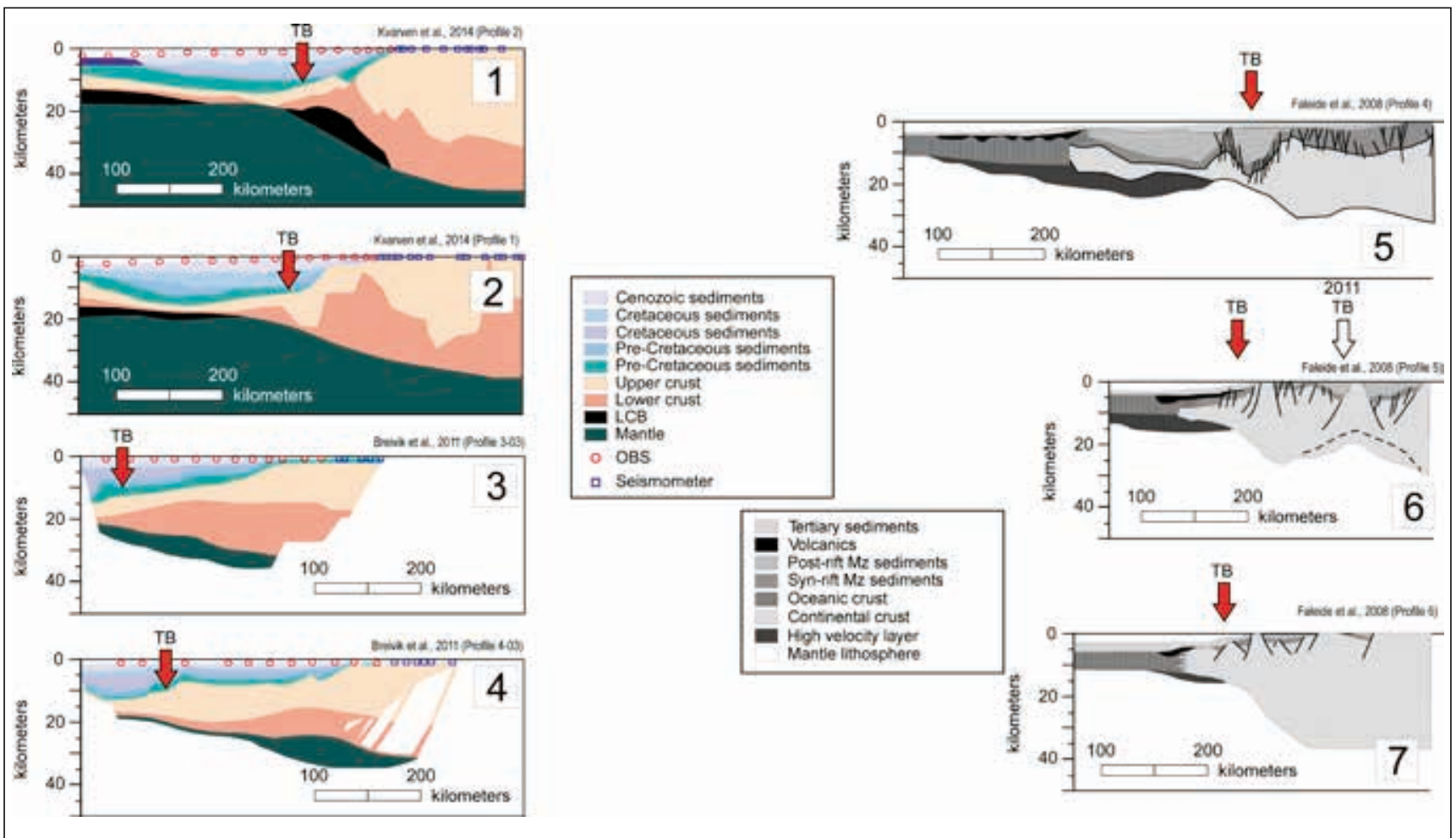

Figure 4. Geoseismic cross sections (modified from Faleide et al., 2008; Breivik et al., 2011; Kvarven et al., 2014) show the 2D location of our updated refraction-based Taper Break (TB). Red arrows denote the TB. White arrow (Profile 6) shows the location of our 2011 TB pick. Here we propose that the TB lies farther offshore (see Fig. 3). LCB - Lower Crustal Body as interpreted by profile authors from Low Velocity Zone data

inner TB (orange diamond symbols). The anti-correlation between the topographic envelope maximum and TB to HBSL distance is also well expressed by our new mapping. Although the slope and R2 coefficient of XY plots such as those shown in Fig. 5 changed subtly, the anti-correlation between the ATL and escarpment height remains one-toone and is very robust.

The petrologic compositions of the inner or outer Low Velocity Zones (LVZs) are not relevant to our interpretation. For example, the location of the TB is insensitive to the alternative geoseismic interpretation of Nirrengarten et al. (2014) which considers at least some of the LVZs to be composed of dense crust (Fig. 6). It is conceptually possible to define an opposing, statistically valid correlation where high elevations are tied to long distances and low elevations to short ones. However, the map pattern describing such a relationship would crosscut the structural grain of the entire Norwegian Sea margin at a very high angle (Fig. 6) and, unlike the ATL, would have no geologic raison dêtre. These data reaffirm our earlier conclusion that, from at least Stadt to the Senja Fracture Zone (and perhaps farther north; see Indrevær et al., 2013 and Schermer \& Redfield, 2013), the height of the Scandinavian mountains is directly related to the crustal thinning gradient imposed during the Late Jurassic shaping of the extended margin.

\section{Fennoscandian seismicity}

During the past near-quarter of Earth history, Fennoscandia's rocks experienced the Sveconorwegian orogeny (ca. 1100-900 Ma), Iapetus and Tornquist rifting (ca. 800 and $540 \mathrm{Ma}$ ), the Timanian and Caledonian orogenies (ca. 580 and $400 \mathrm{Ma}$ ), intrusions related to the East Finland (ca. $500 \mathrm{Ma}$ ) and Kola (ca. 380-360 Ma) Alkaline Provinces, and rifting episodes associated with the formation of today's North Atlantic margin (ca. 250 to $55 \mathrm{Ma}$ ). Defining and mapping a single tectonic entity from the myriad of geologic building blocks that comprise Fennoscandia is correspondingly daunting. Nevertheless, from the perspective of regional seismicity its boundaries can be simply determined.

\section{The seismic dataset}

Several publicly maintained catalogues archive seismic data from the Nordic countries. Despite some mismatches in reported times and locations, the larger magnitude events are broadly consistent across the catalogues. However, very small-magnitude earthquake data vary greatly between the compilations. Most of the differences can be attributed to identification and filtering of anthropogenic events such as construction-related explosions.

During our research we worked with data archived by the United States Geological Survey, the International 


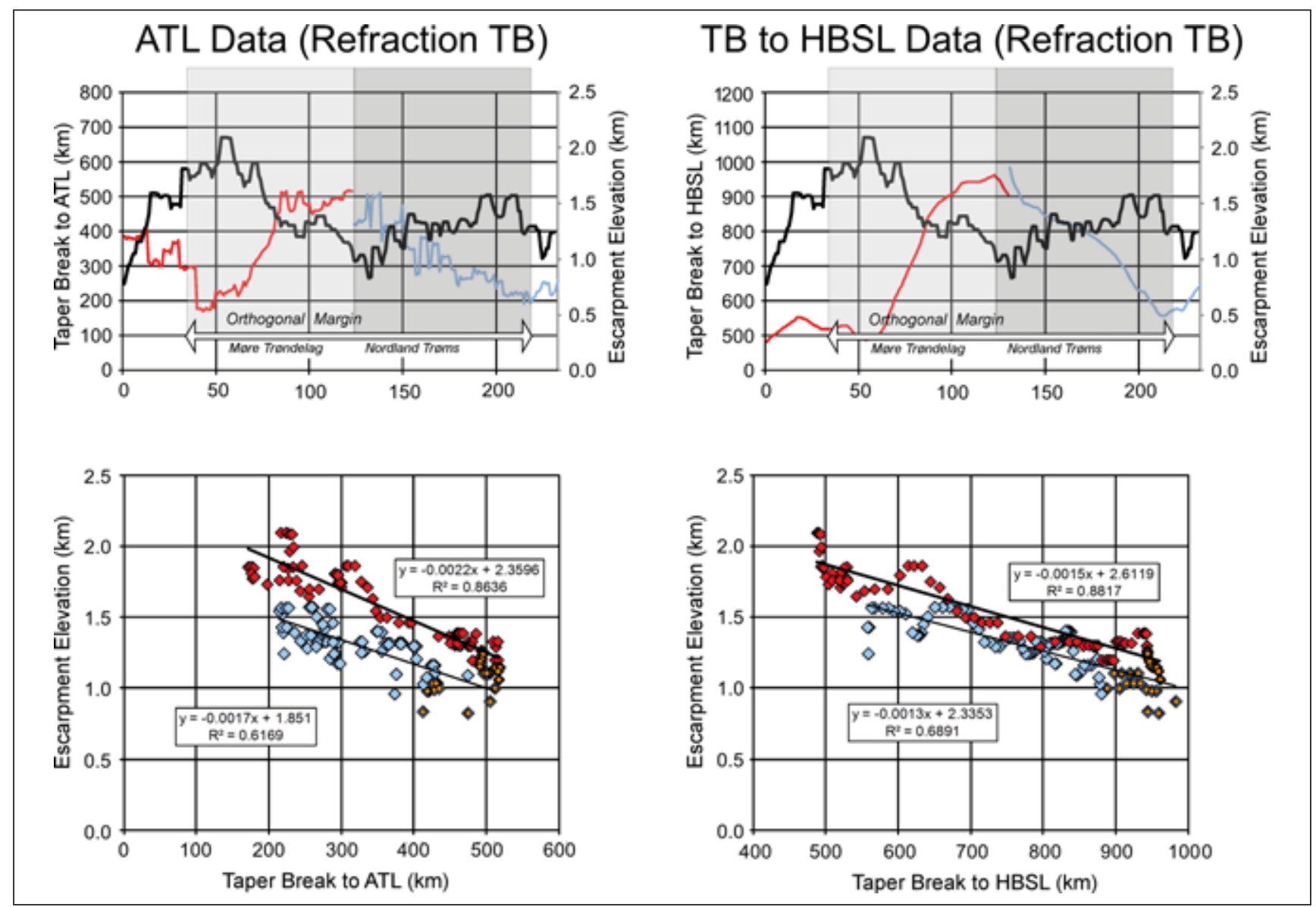

Figure 5. Diagrams illustrating the relationship between the width of the seaward domains (Taper Break to Apparent Taper Length (TB to ATL); diagrams in left column) and the total length of the flexed continental beam (Taper Break to Hinterland Break in Slope (TB to HBSL); diagrams in right column) to the escarpment elevation of the Scandinavian Mountains using our new refraction-based TB (Fig. 3). Top row: Line plot from SW to NE (from Profile 1 to Profile 234 of Redfield \& Osmundsen, 2013) along the topographic crest (Fig. 3) shows a consistent anti-correlation. Note the offsets in ATL and TB to HBSL that occur in the vicinity of the onshore-offshore Møre Trøndelag Fault Complex (MTFC) and TB mega-relays. Red and blue lines denote the MTFC and Nordland-Lofoten-Senja subsets. Bottom row: The degree of anti-correlation is shown in the XY plots for the orthogonally stretched margin. Red and blue symbols denote the MTFC and Nordland-Troms subsets. Orange symbols indicate data from profiles transecting the onshore-offshore mega-relay. The orthogonal margin is mapped in Fig. 3.

Seismological Centre (ISC), the University of Bergen, the Norwegian Seismic Array, and the Finnish Institute of Seismology at the University of Finland, Helsinki (FENCAT; see Ahjos \& Uski, 1992). Because the FENCAT compilation archives events that occurred across the entire craton and its curators meticulously filter anthropogenic sources, we consider it most closely reflects the state of natural seismicity of Fennoscandia.

As the FENCAT dataset is spatially limited to Fennoscandia and its immediate vicinity, we employed the global ISC catalogue to gain a sense of earthquake event density in the rest of the neighborhood. Fig. 1 shows epicenters for $M_{w} \geq 2.0$ events that occurred between 1960 and 2012. The data indicate that a ring of low- to non-existent seismicity surrounds the Nordic countries. Because the ISC dataset has archived Earth temblors throughout more than a half century, we consider the ring of quiescence to have a certain time-proven geologic and/ or geophysical significance. The ring initially parallels the flow-line direction that runs perpendicular to the axis of North Atlantic sea-floor spreading (e.g., Mosar et al., 2002) and subsequently follows the United Kingdom and central European margins of the North Sea graben systems. It continues eastward along the low plains of the Baltic States, loops around the eastern steppes of the former Soviet Union, and moves offshore at the Kanin Peninsula, into the generally aseismic Barents Sea.

For the purposes of this paper we will consider seismic data from the continental and oceanic regions contained within the polygon shown in Fig. 1. The polygon's oceanic realm is roughly bounded by the line marking ca. $10 \mathrm{Ma}$ Penrosetype ocean crust. This cut-off eliminates most earthquakes related to active mid-ocean ridge sea-floor spreading but still includes intraplate earthquakes that occur in and above young-but-aging, North Atlantic oceanic lithosphere such as those near the Bjørnøya Fan (BØF). We further filtered our FENCAT compilation to $\mathrm{M}_{\mathrm{w}} \geq 2.0$ to eliminate uncertainties associated with very small events. Our 


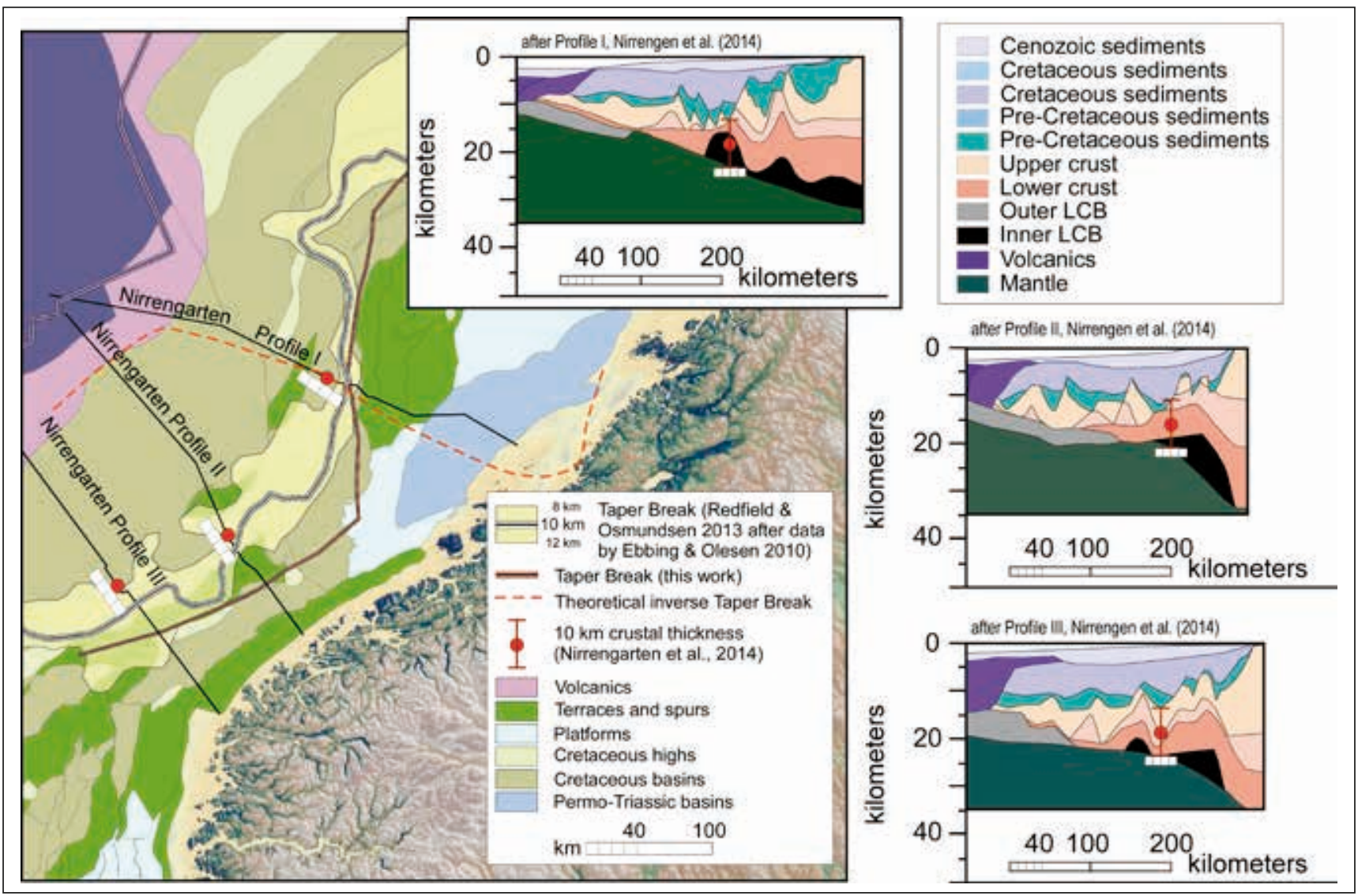

Figure 6. Left: Map showing the Taper Break (TB) as mapped by Redfield \& Osmundsen (2013), this paper, and as discrete picks according to an alternative geoseismic model proposed by Nirrengarten et al. (2014). Lime green $8 \mathrm{~km}$ to $12 \mathrm{~km}$ zone depicts the TB uncertainty described by Redfield \& Osmundsen (2013). Dashed red line depicts an opposing, statistically valid correlation linking low elevations onshore to short ATL as described in the text. Note how this line cross-cuts virtually all of the known structural elements of the Norwegian margin at a high angle. Right: Geoseismic sections after Nirrengarten et al. (2014) with Taper Break picks defined by the most landward instance of $10 \mathrm{~km}$-thick crystalline crust. In this interpretation the inboard Low Velocity Zone (black) has been considered to be part of the crustal density package, e.g., not serpentinized mantle rock. LCB - Lower Crustal Body as interpreted from Low Velocity Zone data by Nirringarten et al. (2014).

final FENCAT dataset approximates the natural, nonanthropogenic seismic signature of Fennoscandia and its adjacent North Atlantic oceanic domain.

\section{An imbalance in the force}

Much of Fennoscandian seismicity occurs inside an oval zone characterized by positive or negative land surface uplift ranging between $-2 \mathrm{~mm} \mathrm{yr}^{-1}$ and $+8 \mathrm{~mm} \mathrm{yr}^{-1}$ (Gudmundsson, 1999; Vestøl, 2006). Immediately outside the oval, far fewer earthquakes occur annually (Fig. 1). However, all is not equal within. As is common between many intraplate regions (Sykes, 1978; Johnston \& Kanter, 1990; Schulte \& Mooney, 2005), many more earthquakes occur on the thinned northeast Atlantic offshore/onshore margin than in the rest of Fennoscandia. Furthermore, the greater amount of seismic energy through time has there been expended. We quantified this statement by measuring and mapping the areal distribution of Fennoscandias Cumulative Seismic Moment $\left(\mathrm{CSM}_{\mathrm{w}}\right)$ energy.

A geodetic spherical cap tessellation was constructed using nearly isosceles triangles with leg lengths of approximately
$7 \mathrm{~km}$ (see Baumgardner \& Frederickson, 1985). The FENCAT $M_{w}$ magnitudes were converted to seismic energy $\mathrm{E}$ using the relationship:

$$
\mathrm{E}=10^{\left(1.5 \mathrm{M}_{\mathrm{w}}+\mathrm{E}_{0}\right)}
$$

where $\mathrm{E}_{0}$ (Joules) is an approximation of the energy released by a small reference earthquake (e.g., Richter, 1958). Each nearly isoceles triangle was populated with the sum of the seismic energy from all earthquakes that occurred within a radius of $16.5 \mathrm{~km}$ of the triangle center divided by the search area $\left(\mathrm{CSM}_{\mathrm{w}}=\mathrm{J} \mathrm{km}^{-2}\right.$. Computation was conducted in an angular reference frame to avoid spatial distortion. The final $\mathrm{CSM}_{\mathrm{w}} \mathrm{km}^{-2}$ energy dataset was expressed as GJ $\mathrm{km}^{-2}$, reprojected to UTM 33N (WGS1984), and gridded under minimum curvature. Our procedure end-runs Nature's inherent complexity by assuming that all of an earthquake's energy is released instantaneously and at one explicit location on a given fault. However, surface or sub-surface rupture lengths for the magnitudes in question should be significantly smaller than the search area radius (see data in Wells \& Coppersmith, 1994). The tesselation method offers a 
consistent method to compare Fennoscandia's release of seismic energy across our entire polygon and is therefore appealing.

Under this treatment, the asymmetric nature of Fennoscandia's seismic budget becomes very clear (Fig. 7). The southeastern, cratonic half of our Fennoscandian polygon is by no means quiescent. For example, the 13752008 FENCAT extended catalogue lists many events estimated or recorded as $\mathrm{M}_{\mathrm{w}} \geq 5.0$ that occurred east of the Oslo Graben. Nevertheless it accounts for only $20 \%$ of Fennoscandia's 1970-2008 instrumented CSM output. The remaining $80 \%$ of the total $\mathrm{CSM}_{\mathrm{w}}$ is located in the northwestern half of the polygon. A similar asymmetry ( $15 \%$ vs. $85 \%)$ is observed if the $39 \mathrm{~km}$ crustal thickness contour approximating the ILE is used as a partitioning line. The imbalance is not caused by our inclusion of North Atlantic earthquakes in the seismic dataset. Fuzzy clusters of $\mathrm{CSM}_{\mathrm{w}}$ are observed in the normally aseismic oceanic domain in the vicinity of the Jan Mayen Fracture Zone and the Senja Fracture Zone/BØF region (Figs. 1, 7), but $>10 \mathrm{Ma}$ oceanic crust elsewhere is essentially devoid of earthquakes. As expressed by $\mathrm{CSM}_{\mathrm{w}}$, the younger lithosphere of the extended continental margin is more seismogenic than the older lithosphere of the craton (see similar conclusions by Sykes, 1978; Johnston \& Kanter, 1990; Schulte \& Mooney, 2005).

\section{Seismicity and the architecture of hyperextension}

Visual inspection suffices to show that Fennoscandian seismicity is partly organized into three discrete and well-defined belts (Figs. 1, 7, 8, 9, 10). Figs. 8, 9 illustrate relationships between the seismic belts as expressed by $\mathrm{CSM}_{\mathrm{w}}$ and a suite of geophysical observations along central profile B-B'. Perhaps most surprisingly, each belt closely tracks a benchmark location of the Norwegian extended margin (Figs. 2, 10).

Reflecting Fennoscandia's overall seismic asymmetry, $\mathrm{CSM}_{\mathrm{w}}$ tends to systematically decrease in magnitude from offshore to onshore throughout much of the orthogonally rifted margin (Fig. 10). $\mathrm{CSM}_{\mathrm{w}}$ is highest in the offshore seismic belt (SB1). Including many of the strongest events in the FENCAT catalogue, SB1 closely follows the TB. Because for much of its length along the Norwegian margin the TB underlies the axes of the major depocenters, SB1 is also spatially associated with very thick Cenozoic and Cretaceous sedimentary deposits (Figs. 8, 11; see Byrkeland et al., 2000; Bungum et al., 2005, 2010; Olesen et al., 2013). SB1 focal-plane solutions tend to be compressional, with hypocenters generally deeper than 15 $\mathrm{km}$ (Hicks et al., 2000). This places many SB1 earthquakes in the crystalline crust or the LVZs.

A less-but-still-reasonably-energetic seismic belt (SB2) runs along the inner proximal margin edge, roughly parallel to and seaward of the asymmetric NW-facing escarpment. The landward boundary of SB2 is effectively the $39 \mathrm{~km}$ crustal thickness contour proxy of the ILE. SB2 hypocenters tend to be shallower than $12 \mathrm{~km}$ and

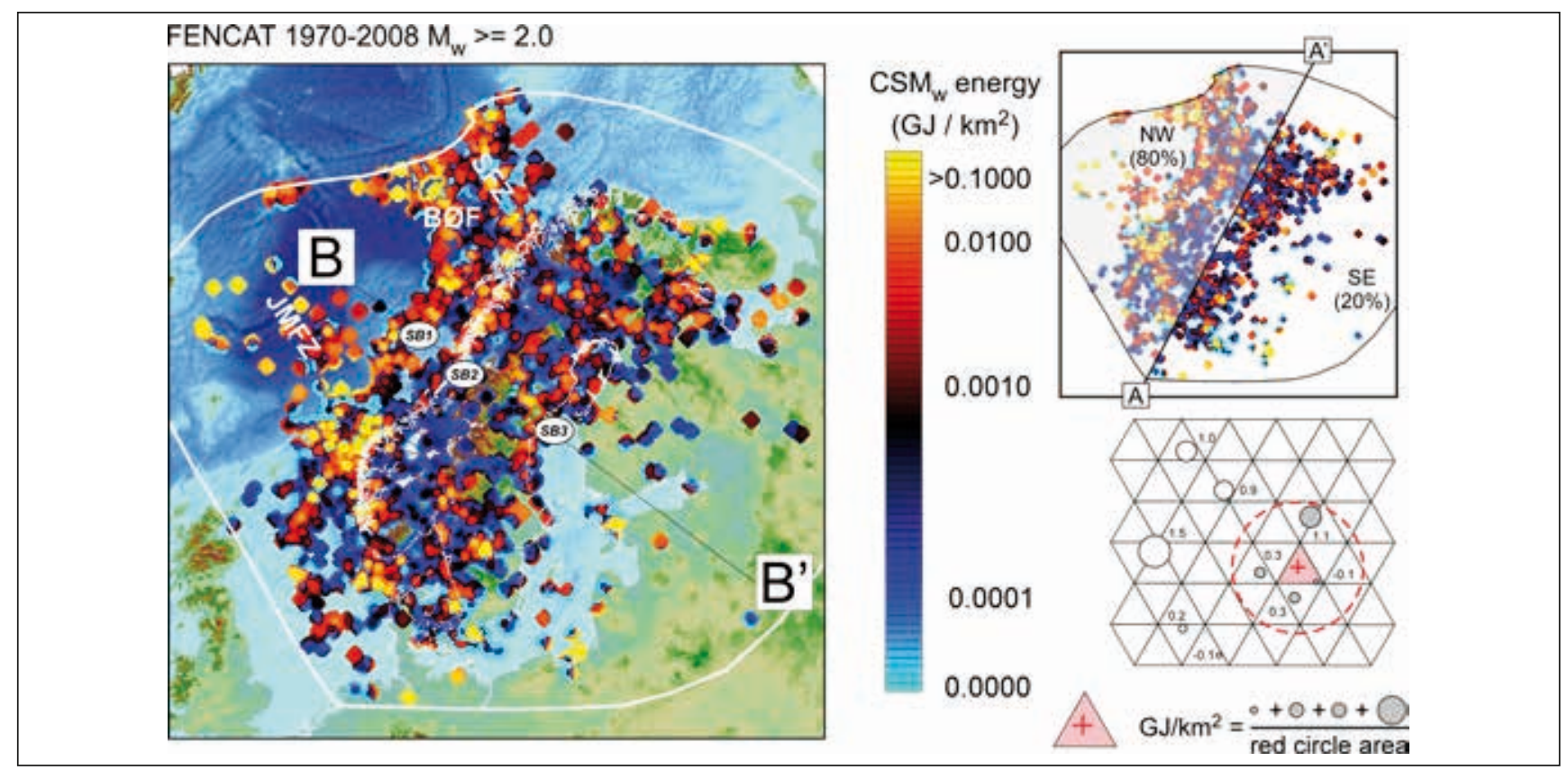

Figure 7. Map showing Cumulative Seismic $M_{w}\left(C S M_{w}\right)$ energy per unit area for Fennoscandia. Data from FENCAT 1970-2008 $M_{w} \geq 2.0$ subset. Profile B-B' refers to cross sections presented in Figs. 8, 9. Extended-margin parallel line A-A' (inset map, upper right) divides the seismic dataset polygon into NW (lightly-shaded) and SE (transparent) domains. Graphic (lower right) illustrates the method of calculation of CSM ${ }_{w}$ as described in the text. BØF - Bjørnøya Fan, JMFZ - Jan Mayen Fracture Zone, SFZ - Senja Fracture Zone. White polygon delimits the FENCAT Baltica subset (see Fig. 1). SB1, SB2 and SB3 denote seismic belts discussed in the text. 


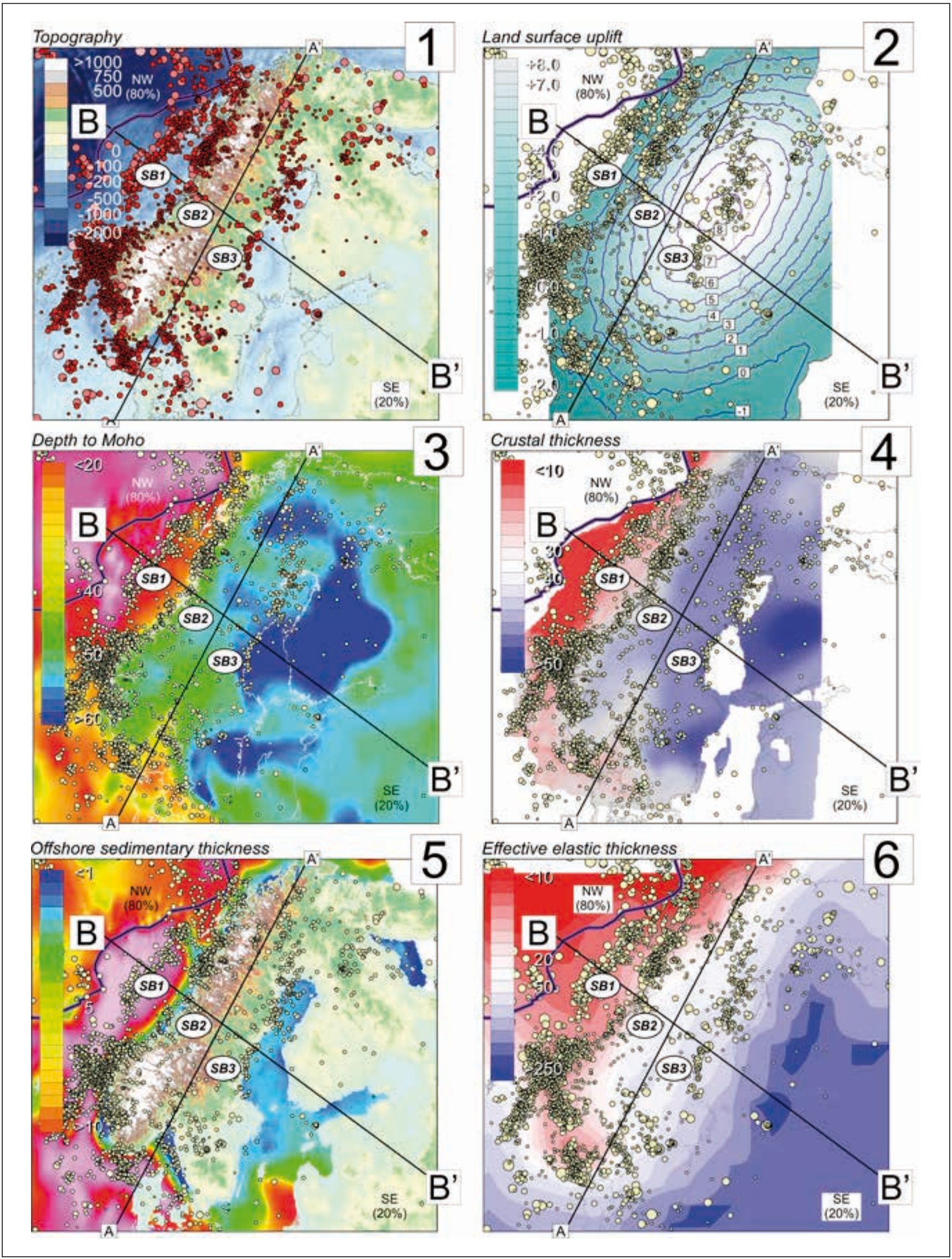

Figure 8. Maps showing spatial relationships between seismicity and (1) topography (data from Andersen et al., 2010), (2) post-glacial land surface uplift (data from Vestøl, 2006), (3) depth to Moho (data from Tesauro et al., 2008), (4) thickness of crystalline crust not including Low Velocity Zones (data from Ebbing \& Olesen, 2010), (5) offshore sedimentary thicknesses (data from Tesauro et al., 2008), and (6) effective elastic lithosphere (data by Pérez-Gussinyé \& Watts, 2005). Line A-A'bisects the seismic dataset polygon (see Fig. 7 inset). Line B-B' indicates cross sections shown in Fig. 9. SB1, SB2 and SB3 denote seismic belts discussed in the text. 
commonly exhibit oblique-normal slip focal-plane solutions (Hicks et al., 2000). The SB2 trace becomes diffuse and its $\mathrm{CSM}_{\mathrm{w}}$ values weaker in the lower elevation sectors of the Mid Norway region (Figs. 7, 11; see Byrkeland et al., 2000).

The third, least-energetic $\mathrm{CSM}_{w}$ seismic belt (SB3) is located at the HBSL, where the tilted Scandinavian hinterland begins to merge with the interior lowlands. SB3 is roughly coincident with measureable increases in crustal thickness (Tesauro et al., 2008; Ebbing \& Olesen, 2008) and lithospheric stiffness ( $\mathrm{T}_{\mathrm{e}}$; Poudjom Djomani et al., 1999; Pérez Gussinyé \& Watts, 2005), as well as the crest of the post-glacial topographic dome (Figs. 8, 9; Gudmundsson, 1999; Vestøl, 2006). Geologically, SB3 also roughly marks the western margin of Fennoscandia's much older cratonic core (Gaál \& Gorbatschev, 1987). Although many of the earthquakes that comprise SB3 are small in moment

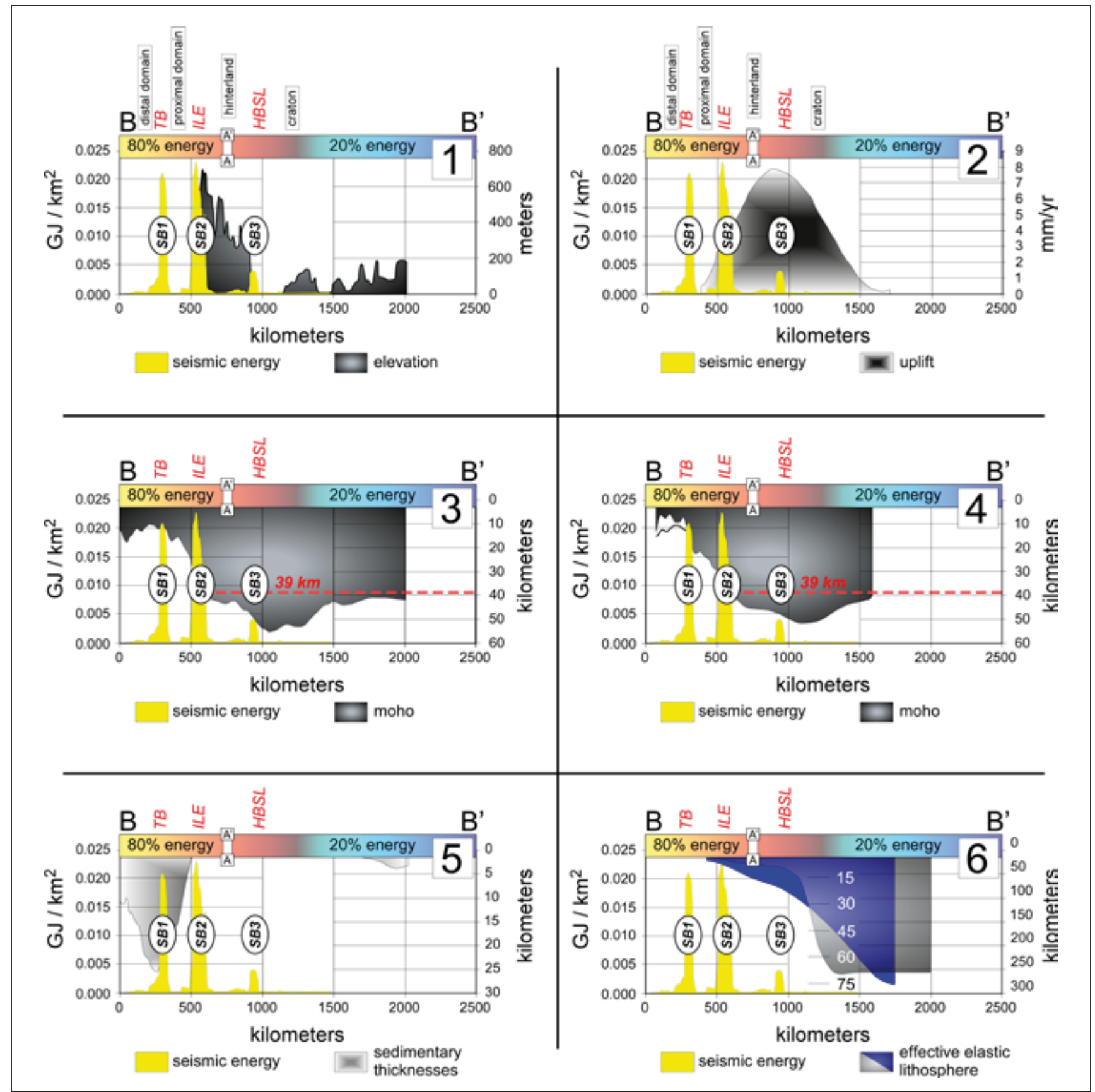

Figure 9. Cross sections showing reduction of Cumulative Seismic Moment $\left(C S M_{W}\right)$ with respect to (1) topographic elevation, (2) land surface uplift (data from Vestøl, 2006), (3) depth to Moho (refraction, reflection and receiver function model from Tesauro et al., 2008),(4) thickness of crystalline crust not including Low Velocity Zones (data from Ebbing \& Olesen, 2010), (5) total sedimentary thickness (data from Tesauro et al., 2008) and (6) effective elastic lithosphere (blue 0-75 km data from Poudjom Djomani et al.,1999; grey 0-250 km data from Pérez-Gussinyé \& Watts, 2005). Location of Profile B-B' shown on maps of Fig. 8. TB - Taper Break, ILE - Innermost Limit of Extension, HBSL - Hinterland Break in Slope. Red dashed line indicates crustal thickness of $39 \mathrm{~km}$, interpreted to represent 'normal' crystalline continental crust (see discussion in Redfield \& Osmundsen, 2013). SB1, SB2 and SB3 denote seismic belts discussed in the text. 

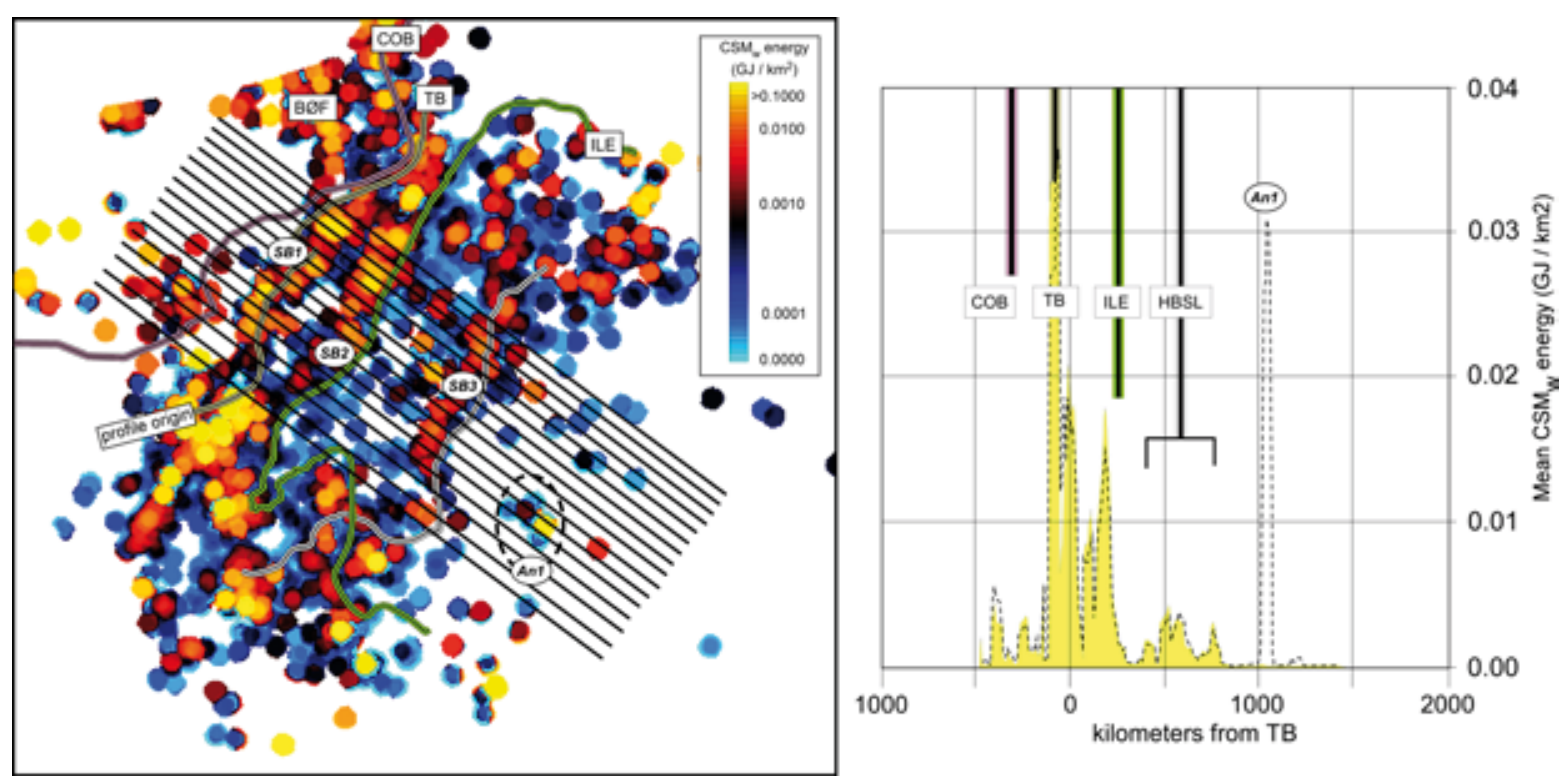

Figure 10. Cumulative Seismic Moment $\left(C S M_{W}\right)$ energy in $\mathrm{GJ} \mathrm{km} \mathrm{km}^{-2}$ computed from the mean of 15 Taper Break (TB) parallel profiles stacked such that the origin of each individual abcissa is located at the refraction-based TB (see Fig. 3). Right: Mean CSM ${ }_{w}$ peaks are interpreted to correlate to the benchmark boundaries of the extended margin: the TB, the Innermost Limit of Extension (ILE), and the Hinterland Break in Slope (HBSL; see Fig. 2). Sharp dashed peak at An1 illustrates a local spike caused by a spatially small cluster of relatively large earthquakes in southern Finland. COB - Continent Ocean Boundary. BØF - Bjørnøya Fan. SB1, SB2 and SB3 denote seismic belts discussed in the text.

magnitude they do not record man-made events. Prior to reporting these data to FENCAT, the local curators explicitly remove all earthquakes suspected to be caused by anthropogenic activity (e.g., Böðvarsson et al., 2006).

\section{Discussion}

Although strong spatial and geophysical arguments have been made for post-glacial rebound as the main perpetrator of Fennoscandia's earthquakes (e.g., Gudmundsson, 1999), less-glaciated (e.g., North America?s southeastern seaboard) and never-glaciated (e.g., South America's southeast Brasilian coast) rifted margins also experience minor, medium, and sometimes major tremors (Sykes, 1978; Johnston \& Kanter, 1990; Assumpção et al., 2011). Moreover, some rifted margins are more seismic than others (op. cit.). This last observation offers a useful test. Models that seek to explain stable continental region seismicity should not predict identical earthquake densities for all rifted margins (see Stein et al., 1989). For example, a sharp GPE gradient theoretically characterizes the world's Continent-Ocean Boundary (COB) contacts. Were COB GPE the sole cause of the intraplate stress field, all rifted margins should exhibit similar frequencies and patterns of earthquakes. However, such likeness does not seem to be the case (Assumpção et al., 2011).

Sykes (1978) suggested that the occurrence of intraplate earthquakes is related to preconditioning factors that created zones of crustal weakness. Fennoscandian rifted margin seismicity robustly reflects the deep-crustal architectural template imposed during the thinning phase (Fig. 10; see The extended margin above), in our view confirming the hypothesis of Sykes (op. cit.). Schulte \& Mooney (2005) demonstrated that some $50 \%$ of $\mathrm{M}_{\mathrm{w}} \geq 4.5$ intraplate earthquakes occur in extended crust (see also Johnston \& Kanter, 1990). The asymmetric distribution of Fennoscandia's CSM $_{w}$ energy (Fig. 10) appears to reflect this partitioning. Below we investigate some implications of these two findings. We then endeavor to place Fennoscandia's seismic system within the framework of a conceptual model consistent with the architectural building blocks defined by Péron-Pinvidic et al. (2013).

\section{What processes are responsible for Fennoscandian earthquakes?}

Between the $\mathrm{COB}$ and the TB, Scandinavia's thinned, faulted, weakened distal margin is largely aseismic. Inboard of the TB, where the thinning gradient is gentle and the landward domains wider, the proximal margin is also aseismic. As noted above, the Scandinavian sector of the TB is intensely seismic. However, although earthquakes are sporadically present along the equally hyperextended Anglican sector to the northwest of Ireland and the Rockall Trough, the density of epicenters is considerably lower, or even null (Figs. 1, 11). When interpreted from the context of the structural and tectonic framework of the entire extended margin, the observed seismic belts, seismic gaps, and the landward decrease in $\operatorname{CSM}_{\mathrm{w}}$ (Fig. 10) provide some important clues as to what drives at least some of Scandinavia’s earthquakes. 


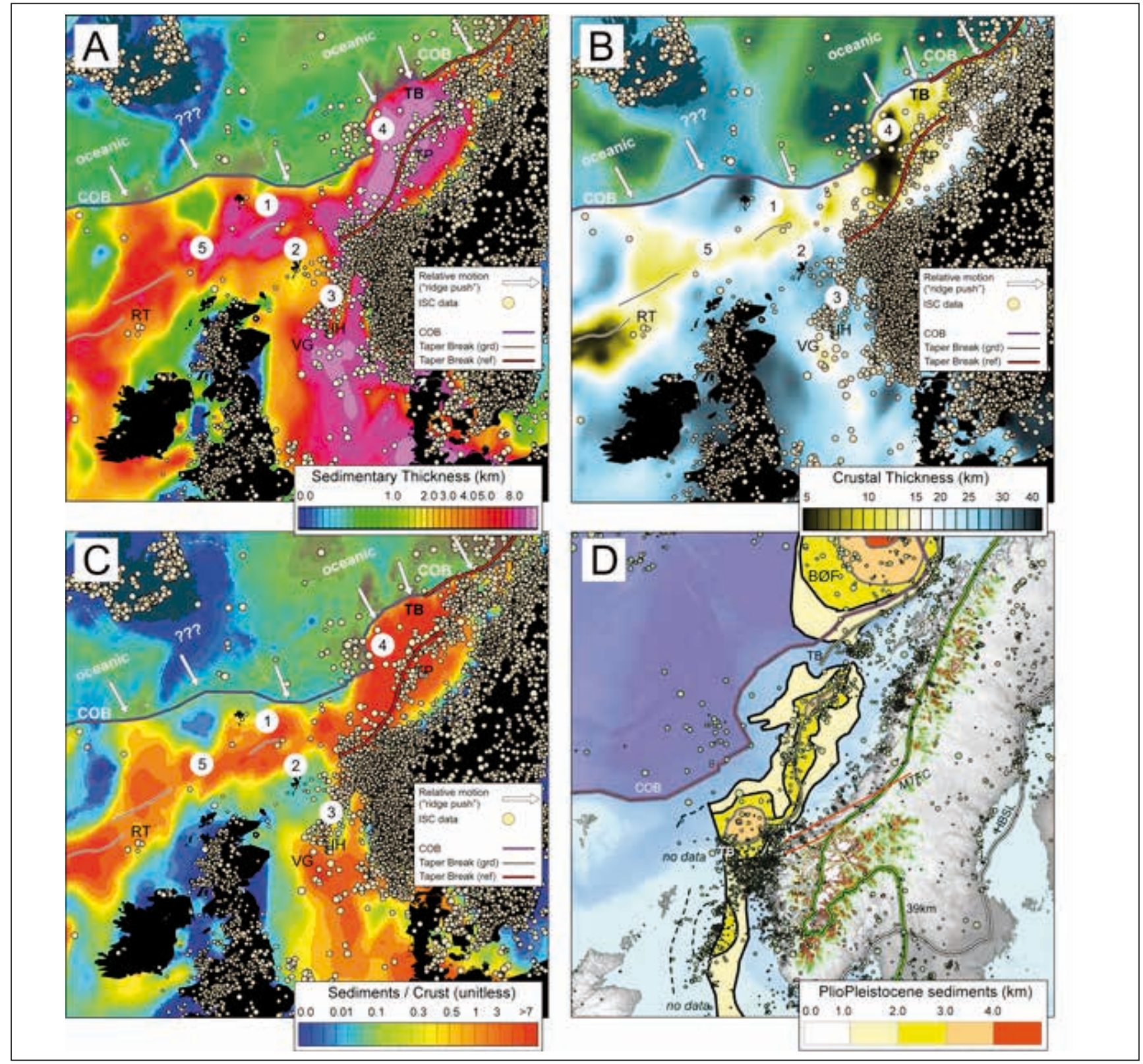

Figure 11. Maps showing (A) sediment thickness, (B) crustal thickness, and (C) the ratio of sedimentary thickness to crustal thickness, each with respect to ISC $M_{w} \geq 2.01990-2012$ seismicity. Crustal model after Tesauro et al. (2008). White arrows show flow-line direction determined from magnetic isochron and fracture zone interpretations (see Mosar et al., 2002). Map (D) shows FENCAT 1970-2008 $M_{w} \geq 2.0$ seismicity with respect to Plio-Pleistocene sedimentation (see Byrkeland et al., 2000. Plio-Pleistocene thickness data from Olsen et al., 2013; supplemented by publications of Skogseid \& Eldholm, 1989; Stuevold, 1989; Rossavik, 1993; Fiedler \& Faleide, 1996; Hjelstuen et al., 1996; Riis, 1996; Hjelstuen, 1997; Rise et al., 2005). Colored DEM data represent the portion of Fennoscandia with topography greater than one standard deviation from the mean, e.g., 'anomalous' topography. Onshore and near-shore seismicity is generally greatest adjacent to these topographic anomalies. RT - Rockall Trough, VG - Viking Graben, UH - Utsira High, TB - Taper Break, COB - Continent Ocean Boundary, BØF - Bjørnøya Fan. TP - Trøndelag Platform, MTFC - Møre-Trøndelag Fault Complex.

\section{How horizontal is the force?}

It is somewhat traditional to consider stresses stemming from plate divergence, Alpine convergence, or some other largely horizontal far-field force to constitute an important driver of Fennoscandian seismicity (e.g., Fejerskov \& Lindholm, 2000; Uski et al., 2003). However, by definition the European TB must extend from the Barents Sea to the Rockall Trough and beyond (Redfield \& Osmundsen, 2013). The linear distance between it and the Mid-Atlantic
Ridge is generally quite similar, and other plate tectonic conditions such as the flow-line azimuth and rate of spreading (Fig. 11; see Mosar et al., 2002) or the age of the oceanic lithosphere (Lundin \& Doré, 1997) are likewise identical. Were ridge push the mechanism responsible for TB earthquakes, we should expect (Stein et al., 1989) them along its complete North Atlantic trace. Furthermore, we should predict (op. cit.) fault reactivation and consequent seismicity across the entirely weakened distal domain. Yet whilst epicenters do cluster near the Jan Mayen and Senja 
fracture zones and throughout the $\mathrm{B} \emptyset \mathrm{F}$, elsewhere the outer domains and the $\mathrm{COB}$ trace are essentially devoid of earthquakes.

Minimal seismicity occurs on the COB (Fig. 11, site [1]) and TB (site [2]) along a traverse parallel to the North America-Eurasia plate motion flow-line in the vicinity of Iceland. However, much farther inboard and along the landward projection of the same flow-line, copious and commonly relatively to very energetic earthquakes occur in the severely thinned crust of the Viking Graben (VG; site [3]). Local CSM measurements there are greater than anywhere else within the limits of our dataset (Figs. 10, 12,13). A similar partitioning occurs in Mid-Scandinavia along Profile B-B' (Figs. 8, 9, 10). Profile B-B' begins atop the oldest, densest oceanic crust of the North Atlantic. The first FENCAT earthquake epicenter - a relatively small and isolated affair - is not encountered until about $100 \mathrm{~km}$ inboard of the COB. The thinned, pervasively faulted, deeply buried outer domains of the Trøndelag Platform are quake-free from the $\mathrm{COB}$ to a nebulous point within $50 \mathrm{~km}$ of the TB, a zone nearly $150 \mathrm{~km}$ in width. Both the refraction and the reflection TBs map near the center of SB1, locally a $\sim 150 \mathrm{~km}$-wide belt. Inboard of this belt lies a $\sim 130 \mathrm{~km}$-wide zone virtually devoid of earthquakes (Figs. 8, 9, 10,11) that persists nearly to the shoreline. Another $\sim 130 \mathrm{~km}$-wide belt of earthquakes and elevated $\mathrm{CSM}_{\mathrm{w}}(\mathrm{SB} 2)$ characterizes the near- and onshore Escarpment Zone. The relatively intense expenditure of $\mathrm{CSM}_{\mathrm{w}}$ in a concentrated belt atop and within thinned crust, the general absence of seismicity throughout the rest of Scandinavias faulted and thinned distal domain and wide swaths of the faulted outer proximal domain, and the presence of a second seismic belt at the faulted inner, thicker proximal domain suggest to us that something other than far-field forces are generating Fennoscandia’s earthquakes.

The importance of vertical loading: To help investigate relationships between seismicity, crustal structure, and sedimentary loading we constructed a unitless grid of sedimentary basin thickness divided by crustal thickness (Fig. 11; data from Tesauro et al., 2008). Where the sedimentary thickness is low relative to the crustal thickness, the ratio will be small (blue colors); where deep sedimentary basins lie on top of thinned crust it will be large (magenta colors). The spatial correlation between offshore seismicity and a large ratio is not entirely consistent. For example, much of the Mid-Norwegian

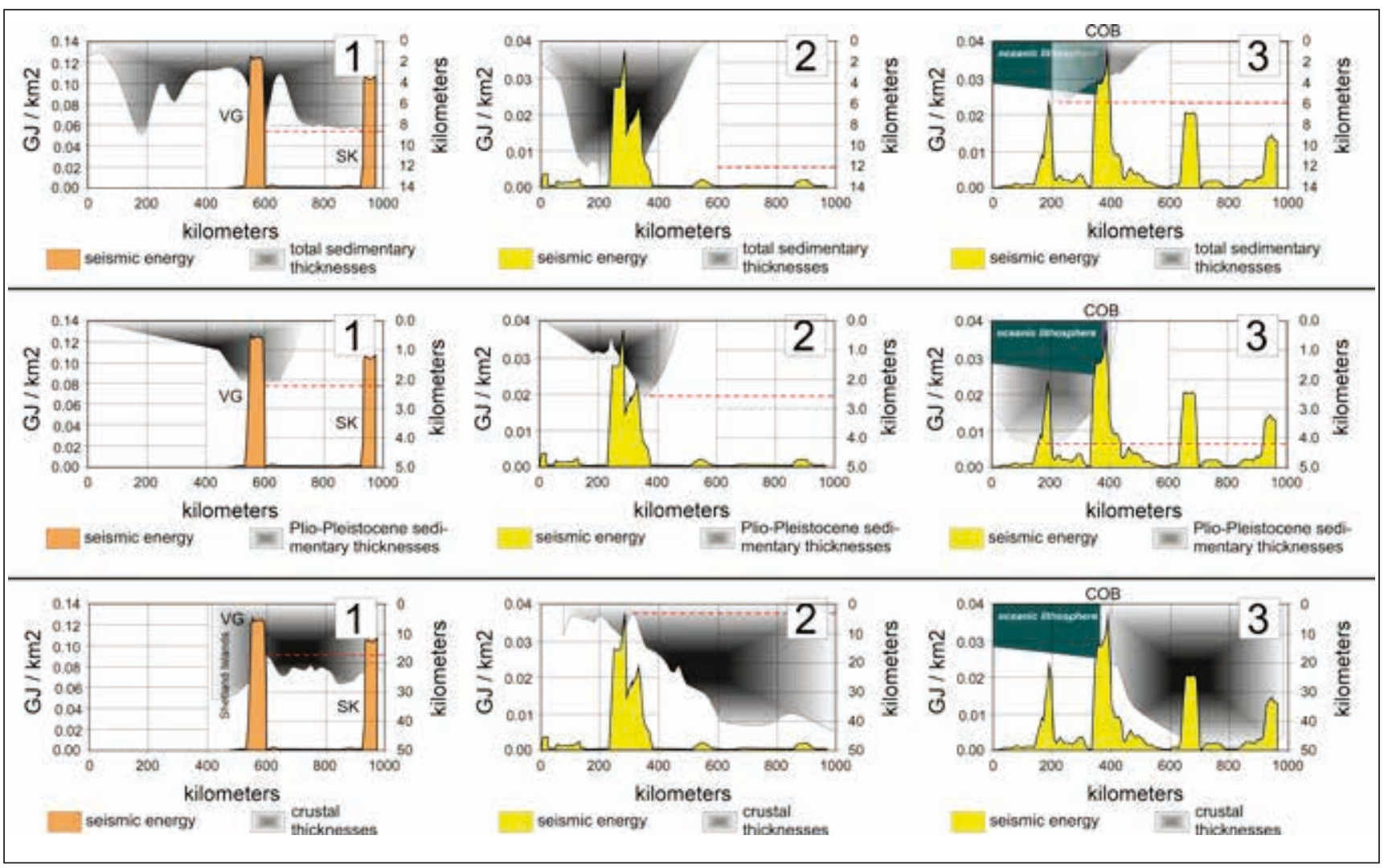

Figure 12. Profiles showing crustal and sedimentary thicknesses with respect to Cumulative Seismic Moment (CSM $M_{w}$. Representative CSM $M_{w}$ rofile data from the full 1970-2008 $M_{w} \geq 2.0$ FENCAT dataset (see Fig. 13 for profile locations. Plio-Pleistocene sedimentary thicknesses from Olsen et al. (2013) and other data as cited in Fig. 11 and other data as cited in previous captions. Total sedimentary thickness data from Tesauro et al. (2008). Crustal thickness data from Ebbing \& Olesen (2010). Thickness of oceanic lithosphere (Profile 3) indicated schematically (not to scale). Note two different ordinate scales, symbolized by yellow and orange histograms: Much more CSM ${ }_{w}$ is present in the Viking Graben profiles (orange). VG - Viking Graben, SK - Skagerrak. Profile locations shown in Fig. 13. 


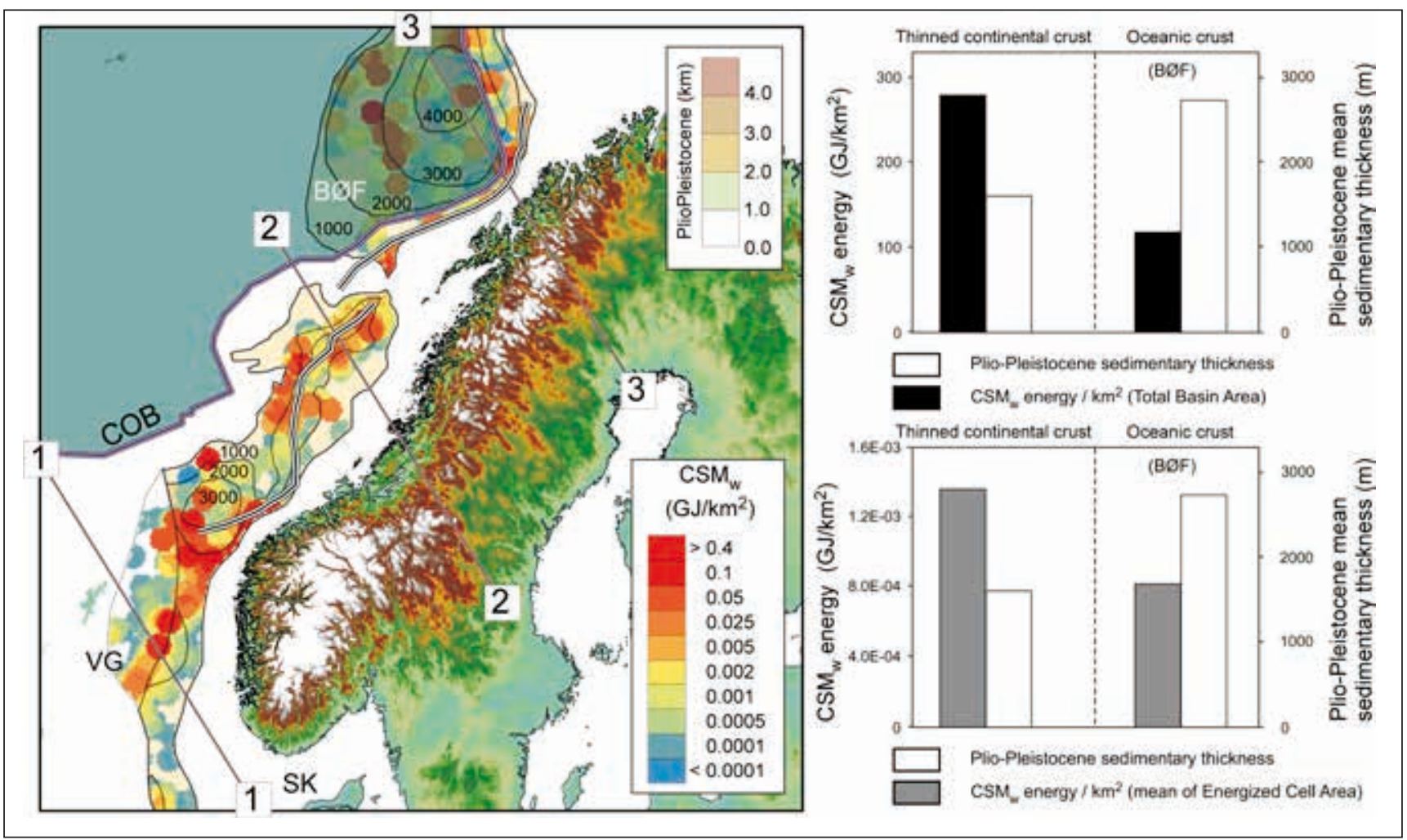

Figure 13. Left: Map showing the subset of tessellation cells populated by Cumulative Seismic Moment (CSM $\left.{ }_{w}\right)$ data greater than zero from areas loaded by $1+\mathrm{km}$ Plio-Pleistocene sediments. CSM from 1970-2008 $M_{w} \geq 2.0$ FENCAT dataset (see text). Plio-Pleisticene mapped at $1000 \mathrm{~m}$ contour intervals after Olsen et al. (2013) supplemented by earlier sources (see Fig. 11 caption). Profiles 1, 2, and 3 are shown in Fig. 12. BØF Bjørnøya Fan, COB - Continent Ocean Boundary, VG - Viking Graben, SK - Skagerrak. The spatial distribution of CSM energy in the BØF region appears less organized; where the crust has been severely thinned, high-energy areas cluster along more linear traces. Right: Bar charts showing energy $\left(\mathrm{CSM}_{w} \mathrm{~km}^{-2}\right)$ against the mean Plio-Pleistocene sedimentary thicknesses $(\mathrm{km})$ for oceanic and thinned continental crust. Whilst a greater sedimentary thickness is present in the dominantly oceanic BØF region, more CSM ${ }_{w}$ energy per total basin area (top) and as averaged per energized tessellation cell area (bottom) is released in areas floored by thinned continental crust near the TB.

distal margin comprises a thick Cretaceous/earliest Cenozoic sag basin probably floored by hyperthinned, faulted crust (Osmundsen \& Ebbing, 2008), yields high (magenta) ratios (Fig. 11, site [4]), and is nevertheless aseismic. Similarly, high (magenta to red) ratios devoid of significant seismicity are resolved on the Anglican TB to the north of Scotland. Along the Mid-Norwegian margin, intense seismicity does occur where the thinnest crust (e.g., the TB) coincides with thick sediments. However, more seems required. Deep sediments lying on top of thinned, faulted crust also do not always generate earthquakes (site [5]).

Stress relaxation in oceanic lithosphere depends partly on the rate at which the load is applied (Bodine et al., 1981). Whilst the evolution of continental lithosphere is much more complicated (e.g., Watts, 2001), it seems reasonable to assume that a similar partial dependency with loading rate should apply. Calling attention to a clear spatial correlation between seismicity and late Plio-Pleistocene glacial wedges, Byrkeland et al. (2000) suggested rapid sediment loading caused reactivation of some of Norway's Mesozoic offshore faults. Bungum et al. $(2005,2010)$ and Olesen et al. (2013) also ascribed Norwegian Sea seismicity to the rough distribution of these deposits.
Seismicity offshore of much of the Norwegian margin is indeed demonstrably constrained to a narrow zone characterized by Plio-Pleistocene sedimentary deposits thicker than $\sim 1000 \mathrm{~m}$ (Fig. 11D). However, the seismically active BØF region, associated with very thick PlioPleistocene sedimentary deposits and floored by what we must presume to be dominantly normal-thickness, largely unfaulted, normally aseismic Penrose-type oceanic crust, presents an informative anomaly.

Bodine et al. (1981) suggested that stress relaxation in oceanic lithosphere should require some 1 to 10 million years. By this measure, the area's Plio-Pleistocene history is very important. Byrkeland et al. (2000) proposed that sediment loads and deposition rates in Plio-Pleistocene time are responsible for the $\mathrm{B} \emptyset \mathrm{F}$ region's high stress fields and corresponding earthquakes, and with this we agree. Yet although the mean thickness of the $\mathrm{B} \emptyset \mathrm{F}$ is nearly a kilometer greater than the Neogene column overlying thinned continental crust of the Norwegian margin, the $B \emptyset F$ 's unitized $\mathrm{CSM}_{\mathrm{w}}$ output is significantly less than the former's (Fig. 13). Furthermore, the BØF's map pattern of $\mathrm{CSM}_{\mathrm{w}}$ energy distribution is more random than the wellorganized, linear to semi-linear clusters that characterize the thinned zones near the TB (Fig. 13). We suggest that 
these differences reflect a fundamental contrast in strength between the dominantly oceanic lithosphere that underlies the $\mathrm{B} \varnothing \mathrm{F}$ and the severely attenuated crystalline continental crust of the TB (see Fig. 12). Extensive Mesozoic structural preparation so weakened the TB lithosphere that the crust in its vicinity was critically stressed and seismically deformed by more moderate Plio-Pleistocene loads (see Zoback, 1992).

\section{Earthquakes and uplift}

The greater majority of Scandinavian workers consistently cite offshore and onshore data that require a period of post-Mesozoic erosional planation to a very low base level followed by $\mathrm{km}$-scale rock column uplift. Examples include sub-cropping and upwarped offshore Mesozoic stratigraphy (Smelror et al., 1994, 2007; Riis, 1996), prograding clastic units (Rokoengen et al., 1995; Brekke, 2000; Faleide et al., 2002), latest Cretaceous Apatite Fission Track (AFT) ages in fault contact with Jurassic or older AFT data at sea-level elevations (Redfield et al., 2004, 2005b; Hendriks et al., 2007, 2010; Osmundsen et al., 2010; Johannessen et al., 2013; Ksiencyk et al., 2014), velocity anomalies in chalk formations (Japsen, 1998), onshore-offshore catchment relationships (Sømme et al., 2009, 2013a, b) and the High-Elevation, Lowrelief Topographic Surfaces (HELOTS) that have been thoroughly studied by generations of geomorphologists (Ahlmann, 1919; Gjessing, 1967; Peulvast, 1978; LidmarBergström, 1999; Lidmar-Bergström et al., 2000) since having first been described as a marker of land surface uplift by Hans Henrik Reusch in 1901. Despite this consensus (see discussion by Hall et al., 2014), a handful of contrarian publications (e.g., Nielsen et al., 2009; Steer et al., 2012) have advanced arguments for no tectonic uplift at all, in large part due to the geological implausibility of commonly advocated mechanisms such as plume- or diapir-related dynamic support (Rorhman \& van der Beek, 1996) or post-breakup tectonic compression (e.g., Løseth \& Henriksen, 2005; Japsen et al., 2012a).

In our opinion, the modern extended margin interpretations reflected in our contribution can help chart a course out of the conundrum. Weakened crust of the TB, one of the benchmark locations of Scandinavia's extended margin and a focus of Plio-Pleistocene deposition, localizes the earthquakes of Scandinavia's SB1 seismic belt. Earthquakes of the SB2 belt are bounded by the ILE and thus also localized by the architecture of the extended margin. Byrkeland et al. (2000) discussed the stressinducing role played by the elevated topography of the Møre, Nordland, and Lofoten coasts, noting that the most elevated provinces host relatively high seismic activity (see also Pascal \& Cloetingh, 2009). As shown above, Scandinavia's escarpment elevations display a one-toone anti-correlation with the sharpness of thinning phase crustal taper (Osmundsen \& Redfield, 2011 and Redfield \& Osmundsen, 2013; Figs. 2, 5). These relationships raise the possibility of a generic model for mountain building at hyperextended rifted margins that can function after the accommodation phase has commenced - even (and perhaps even especially) long after the last vestiges of extension and well into post-breakup time.

Evidence for footwall uplift: Isostatically driven uplift of a normal fault footwall and the corresponding subsidence of its hanging wall (see Agricola, 1556 for the first known use of the terms footwall and hanging wall) is - and has been for some time - well-recognized as a geologic process (Vening Meinesz, 1950; Weissel \& Karner, 1989; Kusznir et al., 1991). It is also considered acceptable by the numerical community. For example, Thompson \& Parsons (2009) produced more than one $\mathrm{km}$ of footwall uplift with a bulk extension of $10 \%$ using a finite element model. Footwall uplift can be confined to the upper crust; seismic imaging from the Basin and Range province shows little or no perturbation of the Moho beneath fault blocks (e.g., Klemperer et al. 1986, echoed by many later studies). However, two problems accompany the application of a footwall uplift model to the Scandinavian mountains. Firstly, crustal extension is not occurring on the Norwegian margin today. In particular, the big faults of the Mid-Norwegian necking domain were onlapped and eventually overstepped at around $100 \mathrm{Ma}$ (see Færseth \& Lien 2002; Osmundsen et al. 2002; Gomez et al. 2004, and references therein). Secondly, although Weissel \& Karner (1989) proposed that permanent rift-shoulder uplift is possible should the lithosphere retain finite mechanical strength (e.g., flexural rigidity) long after extension, an integrated body of evidence by authors such as those cited above indicates that Scandinavia's highlands postdate Late Jurassic to Early Cretaceous crustal thinning. By Late Cretaceous time a significant portion of Scandinavia's Mesozoic rift shoulder no longer existed (see Gabrielsen et al., 2010; Sømme et al., 2013a, b).

Nevertheless, modern structural data, slowly cooled, latest Cretaceous AFT data, and topographic/geomorphic studies indicate that $\mathrm{km}$-scale footwall uplift occurred episodically along certain Norwegian faults, probably throughout much of the Cenozoic (Redfield et al., 2005a; Osmundsen et al., 2009, 2010; Redfield \& Osmundsen, 2009, 2013; Hendriks et al., 2010; Johannessen et al., 2013; Ksienzyk et al., 2014). A particularly fine field example is located near Sortland (Vesterålen), just north of the Lofoten Archipelago. A series of small, nearshore, Mesozoic basins have been mapped along the Norwegian coastline (Bøe et al., 2010). One occurs in the Sortlandsundet as a half-graben (Davidsen et al., 2001). Sedimentary rocks of Bathonian-Callovian age (Fürsich \& Thomsen, 2005) are bounded by a normal fault of at least such an age that itself belongs to the Hadselfjorden Fault Zone (HFFZ) to the southeast. An outcrop of either the basin-bounding fault or a splay to it is exposed onshore in the Rødsand quarry (Fig. 14). This fault is characterized by a $>10 \mathrm{~m}$-wide zone of cataclasite hosting multiple generations of fault rocks that collectively speak of prolonged activity in the brittle regime (Osmundsen et al., 2010). 


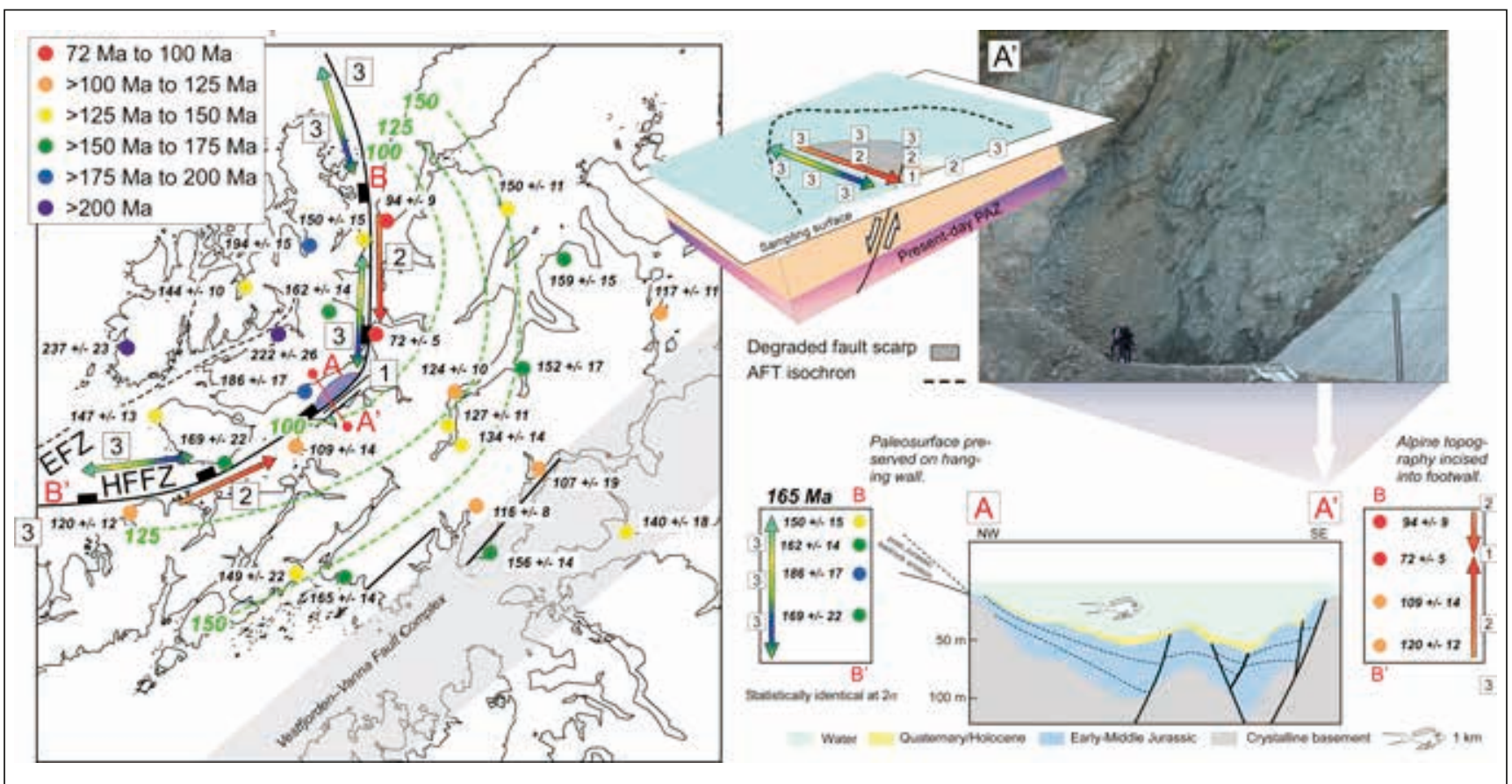

Figure 14. Documentation of km-scale, post-72 Ma, footwall uplift in Vesterålen. Left: Map showing main structures and published near-sea level

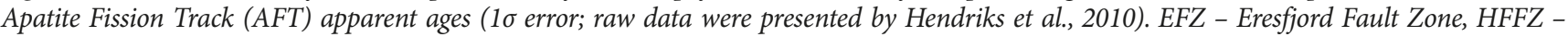
Hadselfjorden Fault Zone. AFT apparent ages colored by age category. The HFFZ hanging wall AFT apparent ages are statistically distinct from their footwall counterparts at the $2 \sigma$ confidence level (Hendriks et al., 2010). Dashed green lines delimit contours of equal AFT apparent age in the HFFZ footwall. Profile A-A'transects the Sortlandsundet Mesozoic sedimentary basin (see Davidsen et al., 2001; Bøe et al., 2010). Profile B-B' follows the trace of the HFFZ. Square boxes [1], [2], and [3] map the conceptual thermochronological age distribution of a large normal fault system where [3] is older than [2] which is older than [1], as shown in the block diagram. Upper right: Photograph of the main damage zone at the Rødsand quarry exposure of the Sortlandsundet bounding fault, located near A'. Two geologists ruminate within the fault core. Lower right: Interpretive geoseismic cross section A-A' after Davidsen et al. (2001) and Ramberg et al. (2006). $1 \mathrm{~km}$-long Jurassic ghoti for scale. An uncertain amount of bedrock has been eroded from the landwards projection of the basin of the Bathonian-Callovian age depositional surface. A conceptual mean AFT apparent age of $165 \mathrm{Ma}$ (conceptually equivalent to [3]) is broadly compatible at the $2 \sigma$ confidence interval along the entire hanging wall side of the HFFZ fault trace. This conceptual age is represented by the green-yellow-blue gradient arrow on both the map and the block diagram. Footwall apparent AFT ages follow the [3] [2] [1] younging-towards-the-point-of-maximum-displacement model trend predicted for AFT-resolvable normal faulting and are represented by the orange-red gradient arrows. [1] is conceptually equivalent to the $72 \pm 5 \mathrm{Ma}$ age near the Rødsand quarry fault. The footwall trend is also statistically significant at $2 \sigma$. It is geometrically impossible to invoke AFT resetting by km+ deep sedimentary burial (e.g., Japsen et al., 2012b) in order to explain the offset and map pattern trends of old hanging wall ages in near-sea-level fault contact with young footwall ages. Figures adapted from Davidsen et al. (2001), Ramberg et al. (2008), Hendriks et al. (2010) and Osmundsen et al. (2010).

New K/Ar data indicate that authigenic illite was forming during latest Jurassic and Cretaceous time within the Rødsand quarry fault core (Davids et al., 2013). Near-sealevel AFT data from the Sortlandsundet hanging wall and footwall are offset at the $2 \sigma$ confidence level (Hendriks et al., 2010; Osmundsen et al, 2010). The youngest nearsea-level footwall AFT apparent age is $72 \mathrm{Ma}$; its presence at the Earth's surface at the base of a $1.2 \mathrm{~km}$ crystalline escarpment, in fault contact with a crystalline hanging wall whose nearest near-sea-level AFT apparent age is $162 \mathrm{Ma}$, requires more than $2 \mathrm{~km}$ of footwall throw since latest Cretaceous time. The short mean track length of the footwall sample (13.13 $\mu \mathrm{m}$; Hendriks et al., 2010) indicates that exhumation was not 'rocket-like' (P.G. Fitzgerald, pers. comm., 1993), but rather a geologically protracted affair. This constraint, plus the textural relationships of the fault rocks in the core, suggests multiple periods of relatively slow uplift probably occurred after $72 \mathrm{Ma}$, potentially throughout the entire Cenozoic.
Standing in stark contrast to the gently-dipping paleic relief preserved on the hanging wall, steep Alpine glacier landscapes incised into the footwall strongly suggest that an antecedent hanging wall footwall drainage system was differentially modified during Plio-Pleistocene time (see discussion in Osmundsen et al., 2010). Furthermore, nearsea level AFT apparent ages of the entire HFFZ hanging wall footwall system obey the fault-parallel age progression predicted by $\mathrm{km}$-scale normal fault throw (Fig. 14; see Redfield et al., 2005a). Re-exhumation of a formerly buried, now exhumed, strictly Mesozoic landscape (e.g., Japsen et al., 2012b) is not plausible. It is far more likely that multiple footwall uplift events juxtaposed both the landscape and today's AFT data along the trace of the HFFZ.

Two other sectors of the Norwegian rifted margin also exhibit evidence for post-breakup footwall uplift (Osmundsen et al., 2010). One is the Lyngen Peninsula of Troms county, northern Norway. Osmundsen et al. (2009) interpreted 
the cross-fjord contrasts in scarp morphology, landscape preservation, the density of very-large-volume rock slope instabilities, and satellite interferometry data as products of a hanging wall footwall normal fault system currently undergoing deformation. The second area is distributed between Møre og Romsdal and southernmost Sør-Trøndelag counties (Redfield et al., 2005a, 2011; Redfield \& Osmundsen, 2009). There, a series of small brittle faults have been mapped just to seaward of the base of Norway's Great Escarpment. Many are associated with the hanging wall damage zone of the Tjellefonna Fault Zone, itself a constituent of the regional MTFC taper-controlled normal displacement gradient (see Redfield \& Osmundsen, 2013). As in Sortlandsundet, these faults are also associated with near-sea-level AFT apparent age juxtapositions separating Jurassic from Mid Cretaceous (Redfield et al., 2004,2005b) or perhaps even latest Cretaceous (Stiberg \& Mørk, 1990) apparent age data. As too in Sortlandsundet, short mean track lengths, multiply-deformed fault rocks with low-temperature mineralization (Bauck, 2010), and contrasting geomorphology (see Etzelmüller et al., 2007) suggest that rock column uplift was the result of several periods of faulting throughout the Cenozoic.

\section{A conceptual seismological model}

The Lyngen, Sortland, and Møre og Romsdal areas each lie adjacent to a sharply tapered sector of the Norwegian rifted margin. Osmundsen \& Redfield (2011) and Redfield \& Osmundsen (2013) proposed a conceptual model linking reactivation of some of Norway's brittle normal faults with the continuing adjustment of the rifted margin stemming from erosional unloading and depositional loading. Here we amplify our 2013 model and place it within a seismological framework.

A thin-plate hypothesis: We begin by assuming that the elastic property of the Fennoscandian lithosphere can be described by a thin plate with uniform effective elastic thickness $\left(\mathrm{T}_{\mathrm{e}}\right)$ for the entire model domain. This classical and time-honored working hypothesis (Gunn, 1943; Vening Meinesz, 1950) has been adopted by many geophysically inclined authors (see Gilcrist \& Summerfield, 1990; Gunnell \& Fleitout, 1998) even though "The treatment is theoretical and, in view of the evident complexities in structure of any real edge, it is greatly simplified" (Walcott, 1972). A more realistic model would describe lithospheric necking, cooling, and the reduction in crustal thickness with horizontally and temporally variable $\mathrm{T}_{\mathrm{e}}$ (see below). However, the necessary mathematical gymnastics and known unknowns tend to obscure the simple physical ideas we wish to explore.

Following extension, excision-related proximal margin uplift is considered to give way to post-thinning lithospheric cooling and subsidence (McKenzie, 1978). Progressively increasing flexural rigidity of the lithosphere of the landward domains is one consequence (Stephenson, 1984; Chase \& Wallace, 1988). Another is the inevitable onset of erosion. Because the TB marks the point where large fault arrays can potentially cut through the entire crust, it represents a structural and rheological point of permanent weakness (e.g., Sutra et al., 2013; see The extended margin, above). In our conceptual model, the TB functions as a flexurally weak, margin-parallel axis of deposition that separates the landward and seaward domains and is forever susceptible to subsidence and increasing accommodation space.

Over time, erosion from the syn-rift escarpment to the TB's basins will cause a significant lithospheric-scale bend (Walcott, 1972; Turcotte \& Schubert, 1982; Watts, 2001; Watts et al., 2009). By creating fore-bulges, flexural bending generates both compressive and tensile fiber stress (e.g., Watts, 2001; see Fig. 15, top). Thus, the reduction of rift-era escarpments throughout the sag period will be accompanied by an ever-evolving state of stress that follows a generally predictable trajectory. Progressively greater rigidity coupled to the inexorable increase in load will cause the proximal flexural bulge to migrate landward (see Stephenson, 1984). One potentially important implication is that as lithospheric cooling, subsidence, and bulge migration continue, a wave of compression may begin to overprint structures that initiated under earlier, more tensile conditions. Some of the reverse stress fields recorded by offset borehole traces at roadside outcrops in Scandinavia's onshore proximal domain (Pascal et al., 2010) may reflect this hypothesis.

In the absence of stiffening processes such as the volcanic intrusions observed in the Norwegian Sea's outer domains, the faulted crust of the distal domains will remain unhealed throughout the life of the rifted margin. The mechanically weakened state of the mantle underlying the $\mathrm{TB}$ and the permanently contrasting material properties of the distal and necking domains cause the maximum compressive bending stress condition to remain localized, also throughout the life of the margin. This condition effectively precludes the use of a continuous thin plate of constant rigidity in even a hypothetical mode. We therefore upgrade our conceptual model to invoke an almost-butnot-quite-broken thin plate that constitutes two nearly physically separated 2D beams located respectively to landward and seaward of the TB (Fig. 15, bottom).

Fig. 15 (bottom) depicts the top surface of the upgraded 2D model thin plate at one snapshot in post-breakup space-time. Bending stress can be computed using mathematics shown in Table 1 (see Watts, 2001 for a more rigorous discussion) and is shown in our model as the heavy black line. Because rock will fail under either tension or compression provided sufficient stress is applied, discrete zones exist along the model profile where failure is theoretically required. In our upgraded model, flexural bending in response to Plio-Pleisticene offshore sedimentary loading drives the observed alternating seismogenic zones and seismic gaps (e.g., Figs. 1, 7, 10, 15; see Ludwig et al., 1966; Turcotte et al., 1978; Bodine et al., 1981; Christensen \& Ruff, 1988). 


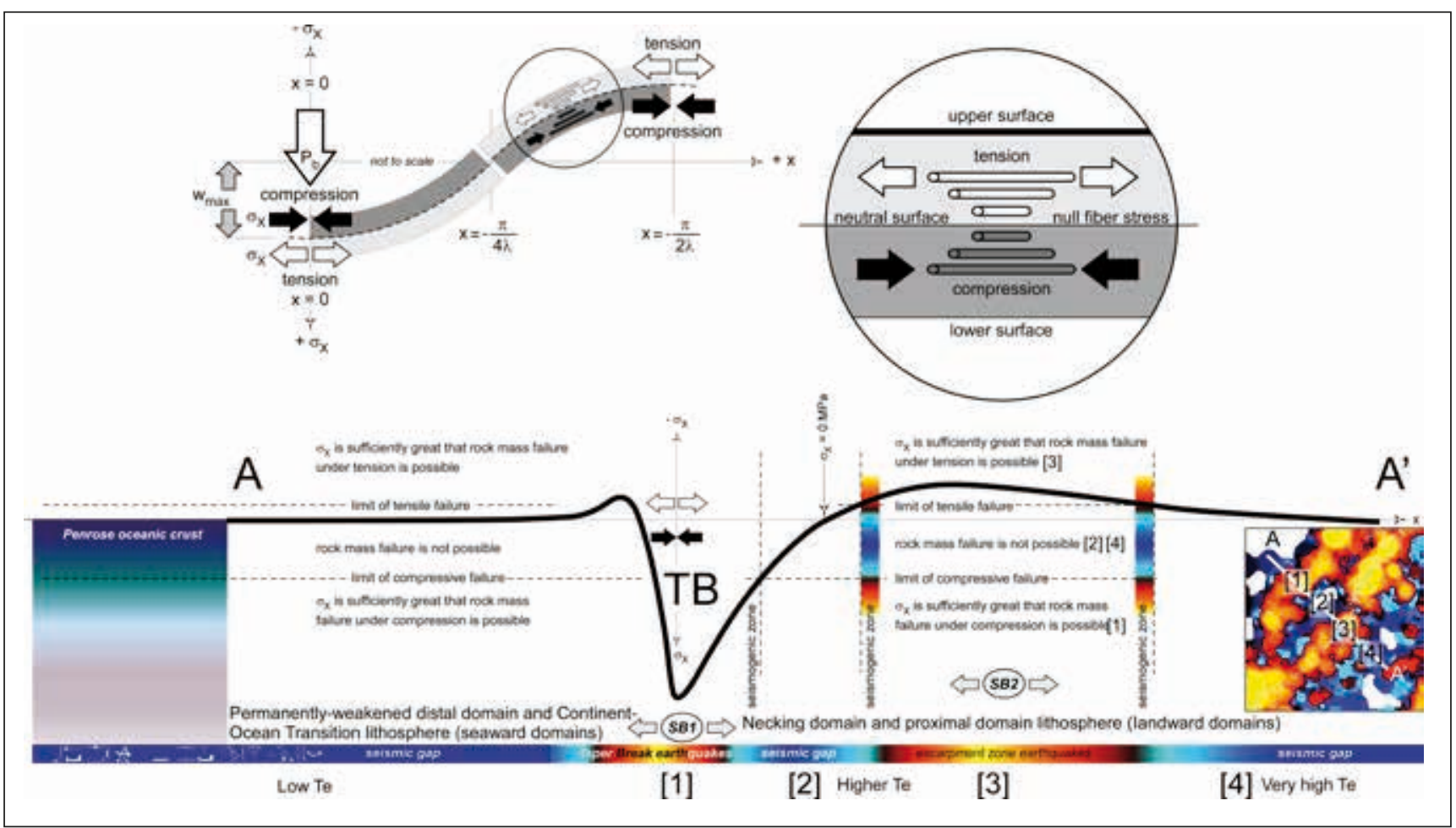

Figure 15. A slightly numericized conceptual model. Top: Cartoon showing a flexed two-dimensional beam of rock of constant-thickness $T_{e}$ and possessed of a constant flexural rigidity. Bending (fiber) stress $\sigma_{x}$ refers to the tensile or compressive state of a one-dimensional rod occupying a particular position within the beam (circled inset). Equations that govern the bending stress $\sigma_{x}$ of any abscissa position $x$ along the upper surface of the beam are given in Table 1. Bottom: Theoretical distribution of fiber stress in two loaded beams of constant but very different stiffness (elastic thickness), separated by the Taper Break (TB). Shown as heavy black lines, $\sigma_{x}$ is the ordinate to abscissa distance $x$. In keeping to convention, negative $\sigma_{x}$ values (up) indicate tension and positive $\sigma_{x}$ values (down) indicate compression. In this model, earthquakes can be driven by flexural bending in locations where the absolute value of the bending stress $\sigma_{x}$ exceeds either the tensile or the compressive failure limits of the (hypothetically homogeneous and undeformed) rock (e.g., Ludwig et al., 1966; Turcotte et al., 1978; Christensen \& Ruff, 1988; see equations in Table 1). Colored bar at the bottom refers in a cartoon manner to cross section B-B' in Fig. 7. Map inset refers to Figs. 7, 10.

Earthquakes will be favored adjacent to the TB (Fig 15, site [1]) where maximum compressive bending overprints a zone of mechanical contrast that, by itself, probably helps concentrate stress (Jaeger et al., 2007). Farther towards land, bending stress decreases; past a certain point (and therefore below a critical compressive stress level) seismicity ceases (site [2]). Somewhere near the emergent part of the proximal domain, tensile stress surpasses another critical level (site [3]). Although true tension (e.g., negatively signed stress) cannot exist in the Earth at any great depth (Zoback, 2007), rock can still break if the least compressive stress approaches the value of the local pore pressure (op. cit.). Finally, farther towards the hinterland, the lithospheric bend becomes less; neither tensile nor compressive bending stresses are sufficient to cause earthquakes (site [4]). In a hypothetical sense the lithospheric inflection coincident with the HBSL (Fig. 2; not shown on Fig. 15) may constitute a point where compressive bending stress is again capable of fault reactivation at shallow crustal levels.

It is conceptually plausible that within seismic zones SB1 and SB2 the opposing bending stress at some distance below the neutral surface would also exceed local rock strength. However, it is difficult from a practical perspective to define the absolute values of controlling parameters such as the depth in the lithosphere where the switch in stress regime would occur or where ductile processes become sufficiently important that differential stress can be accommodated by plastic deformation. A point to note is that the theoretical bending stress maxima both above and below the neutral surface will occur at the same locations along the abcissa. Both tensional and compressional earthquakes can, in principle, be accommodated by a flexural bending model, albeit at different depths.

A more complete model: Flexural bending and the accompanying stress field predicted by thin-plate theory is well documented in nature (e.g., Ludwig et al., 1966; Turcotte et al., 1978; Christensen \& Ruff, 1988; Grollimund \& Zoback, 2003; Watts et al., 2009). However, the bending stress mechanism clearly cannot constitute the sole cause of Fennoscandian seismicity. Four other locally important factors act in concert to amplify the bending stresses of lithospheric flexure.

As well as increasing the amplitude of the longterm flexural bend, Neogene sedimentation into the depocenters near the TB imposed a recent and rapidly 
Table 1. Parameters and equations of the slightly numericized conceptual thin-plate model (Fig. 15). Original formulations and mathematical derivations can be found in Watts (2001) or Turcotte \& Schubert (1982). Nomenclature follows Watts (2001).

\begin{tabular}{|c|c|c|}
\hline$E$ & Young's modulus & $\begin{array}{l}\text { A suite of well-known equations describe the flexural properties of a thin elas- } \\
\text { tic plate or beam. We use the notation and formulations of Watts (2001). }\end{array}$ \\
\hline $\mathrm{v}$ & Poisson's ratio & \multirow{3}{*}{$\alpha=\frac{1}{\lambda}=\left[\frac{4 \mathrm{D}}{\mathrm{g}(\rho \mathrm{m}-\rho \mathrm{i})}\right]^{1 / 4}$ and $\sigma_{\mathrm{x}}=\frac{\mathrm{E} \mathrm{T}_{\mathrm{e}} \mathrm{P}_{\mathrm{b}} \lambda^{\mathrm{S}}}{2 \mathrm{~g}\left(1-\mathrm{v}^{2}\right)(\rho \mathrm{m}-\rho \mathrm{i})} \mathrm{e}^{-\lambda \mathrm{x}}(\cos \lambda \mathrm{x}-\sin \lambda \mathrm{x})$} \\
\hline g & gravitational acceleration & \\
\hline$\rho m$ & mantle density & \\
\hline$\rho i$ & infill density & \multirow{3}{*}{$\begin{array}{l}\text { The point of maximum deflection ( } \mathrm{w}_{\max } \text { ) of a continuous thin plate of rigidity } \mathrm{D} \\
\text { caused by the line load } \mathrm{P}_{\mathrm{b}} \text { is defined to occur at } \mathrm{x}=0 \text {. Therefore }\end{array}$} \\
\hline$T_{e}$ & effective elastic thickness & \\
\hline $\mathrm{D}$ & flexural rigidity & \\
\hline $\mathrm{P}_{\mathrm{b}}$ & line load & \multirow{2}{*}{$\mathrm{w}_{\max }=\frac{\mathrm{P}_{\mathrm{b}} \lambda}{2 \mathrm{~g}(\rho \mathrm{m}-\rho \mathrm{i})} \quad$ or $\quad \mathrm{P}_{\mathrm{b}}=\frac{2 \mathrm{gw}_{\max }(\rho \mathrm{m}-\rho \mathrm{i})}{\lambda}$} \\
\hline $\mathrm{w}_{\max }$ & maximum deflection & \\
\hline$\alpha$ & flexural parameter & \multirow{5}{*}{$\begin{array}{l}\text { Fiber stress } \sigma_{x} \text { at the top surface of the thin plate at locality } x \text { is found using } \mathrm{w}_{\max } \\
\text { instead of } \mathrm{P}_{\mathrm{b}} \text { by substitution and simplification of the remaining terms by factoring. }\end{array}$} \\
\hline$\lambda$ & flexural parameter & \\
\hline$\sigma_{\mathrm{x}}$ & fiber stress & \\
\hline$x$ & distance & \\
\hline & & \\
\hline
\end{tabular}

applied, 'downward' vertical load (e.g., Byrkeland et al., 2000). This still-equilibrating (see Bodine et al., 1981) vertical stress field amplifies the compressive effect of bending. Similarly, erosional reduction of latest Cretaceous and Early Cenozoic escarpment topography generated local 'upward-directed' stress in the proximal domain (Byrkeland et al., 2000). Its practical effect is to augment the tensile thin-plate bending stress. The upward load may be very effective (e.g., Medvedev \& Hartz, 2015). Sediments generally fill more volume than did the original crystalline bedrock; offshore Scandinavia today they displace water whereas the source that was removed has been replaced only by air. Under these circumstances erosion can produce a greater local stress than deposition.

Proximal domain tensile bending stress will also be directly complemented by excess seaward-directed GPE derived from the contrast between crystalline bedrock and either air or the deep basin sediments (see Pascal \& Cloetingh, 2009). Numerical modeling studies have indicated theoretical GPE values on the order of $-2 \times 10^{12} \mathrm{~N} \mathrm{~m}^{-1}$ (Bott, 1991; Pascal \& Cloetingh, 2009). Finally, post-glacial land surface rebound is responsible for rapidly imposed upward and downward bending stress across Fennoscandia's continental thin plate (Gudmundsson, 1999). During periods of post-glacial rebound, isostatic subsidence outboard of the glacio-isostatic hinge will reinforce compressive stress in the vicinity of the Scandinavian TB, whilst uplift inboard of the hinge will simultaneously amplify tensional stress at the inner proximal margin. The maximum post-glacial uplift rates map near the HBSL (see Fig. 8), where a sharp $\mathrm{T}_{\mathrm{e}}$ gradient (Poudjom Djomani et al., 1999; Pérez-Gussinyé \& Watts, 2005; Figs. 8, 9) may conspire with rapid, ongoing, post-glacial deformation and the predictions of flexure to preferentially localize reactivation of pre-existing faults and fractures in the
Fennoscandian basement (e.g., Grollimund \& Zoback, 2001). In our conceptual model, continental deglaciation shifts Fennoscandia's seismicity into top gear, whereas continental glaciation applies the brakes.

The model ideal: Missing in our model as developed so far is the geometry of crustal taper. Because a not-insignificant portion of the strength of the lithosphere can reside in the crust, it follows that as the crustal wedge thickens towards land its snapshot-in-time flexural rigidity should also increase. Similarly, the along-axis variation in taper that correlates directly with escarpment elevation (see Some new results, above) must be accommodated in $3 \mathrm{D}$ (xyz space) as well as through 4D (time). The numerical construction of this type of model lies outside the scope of our paper. It is also a tall order. Beyond its obvious computational complexity, one significant conceptual problem facing an ideal model is how to quantitatively predict and accommodate the myriad of pre-existing basement structures and other inhomogeneities on all scales that fundamentally govern the response of a natural rock body to even small changes in stress (Munier \& Talbot, 1993; Sibson, 1994; Mattila \& Viola, 2014).

\section{Stress and modes of taper}

Our Scandinavian field observations indicate that major faults and fault zones adjacent to sharply tapered proximal domain sectors underwent km-scale, normalsense footwall reactivation in latest Cretaceous and Cenozoic time. (Although brittle regime faults do crop out along more gently tapered sectors, their postbreakup reactivation has not been resolved with the tools at our disposal.) Because fault reactivation is quite commonly seismic, a one-to-one correspondence between earthquakes and crustal taper is indicated in Scandinavia. 
Where taper is sharp, the offshore load lies relatively close to the ILE. Tensile bending stress and high GPE were probably present near the coastlines immediately following thinning-phase necking, creating conditions favorable for normal fault formation or reactivation and consequent footwall uplift. Subsequent erosion of the escarpments induced more upward- and seawarddirected stress, initiating a positive feedback. Where taper is gentle, the TB and its subsiding depocenters lie farther outboard. The bending stress of flexural arching was and remains distributed across a much greater distance. Stress conditions near these coastlines were less amenable to normal faulting; little to no footwall uplift was favored, leading in turn to less incision and greater long-term landscape stability.

A certain degree of structural preparation may be necessary to erect a topographically significant postbreakup escarpment. As with many ancient continents, Fennoscandian bedrock is heavily fractured and commonly faulted, even at deep crustal levels. For example, pre-Caledonian ductile and penetrative strains in rocks in eastern Sweden became increasingly localized as mylonitic zones that later evolved into faults once exhumation placed them above the brittle-ductile transition (Munier \& Talbot, 1993). Many shear zones subsequently widened, developing into fracture/fault zones with a sufficiently wide range of orientations that any subsequent strain could be readily accommodated (Munier \& Talbot, 1993; Mattila \& Viola, 2014). Where pre-existing major structural zones such as Mid Norway's MTFC present a suitably marginparallel orientation and are located an appropriately short distance from the TB, spectacular and sharply asymmetric coastal mountains may result. Where big shear zones are absent or lie beyond the critical distance, fault- and fracture reactivation might still be possible if structural maturity (e.g., structural saturation; see Mattila \& Viola, 2014) has been achieved. However, flexure may replace rupture as the dominant mode of topographic control.

\section{The model abroad}

Relationships between seismicity and lithospheric flexure are well accepted. More than one generation of authors has considered bending stress to be a fundamental driver of outer-rise earthquakes at major subduction zones (e.g., Ludwig et al., 1966; Turcotte et al., 1978; Bodine et al., 1981; Christensen \& Ruff, 1988). Pritchard et al. (2007) documented relationships between intraplate bending stresses and faulting/seismicity in Hawaii. Grollimund \& Zoback (2003) specifically suggested that stresses induced by lithospheric flexure can explain the general E-W stress orientation as well as a more subtle stress field rotation that is observed in the northern North Sea. Most recently, a thought-provoking contribution proposed that lithospheric flexure related to anthropogenic water depletion and natural annual recharge in California's San Joaquin Valley is systematically reducing effective normal stress on the San Andreas Fault, providing a viable mechanism for the observed seasonality of microseismicity recorded in nearby Parkfield (Amos et al., 2014).

A fair question is whether or not other rifted margins display similar relationships between earthquakes and rift architecture. We thus cast our eyes briefly towards the southeast margin of Brasil, where both the concepts of hyperextension (Zalán et al., 2011) and a strikingly similar seismological model (Assumpção et al., 2011) have recently been proposed. Lima et al. (1997) suggested that offshore sediment loading on the continental shelf can produce the coast-parallel $\mathrm{Sh}_{\max }$ observed in borehole breakouts from the onshore parts of many marginal basins (see Reis et al., 2013). Lima et al. (1997) also proposed that local sources of stress at the eastern continental margin may have been underestimated in the theoretical stress models of the South American plate. In answering their own very pertinent question "How active is a passive margin?" Bezerra \& Vita-Finzi (2000) hinted that flexural bending stemming from sediment loading offshore (see Assumpção, 1992) drove (or at least helped drive) activity on a set of faults inland of Forteleza and Natal (Northeast Brasil) during Neogene time. Watts et al. (2009) demonstrated that loading of the Amazon Fan generated a flexural depression of $2 \mathrm{~km}$ or more centered above crystalline basement only a few km thick. Citing borehole breakout data, Watts et al. (2009) also showed that the tensional and compressive bending stresses predicted by thin-plate theory are present in the upper rock column on both sides of the depression.

In Southeast Brasil, post-breakup country-rock exhumation from depths between 2 and $5 \mathrm{~km}$ has been interpreted from low-temperature thermochronology (Gallagher et al., 1994; Franco-Magalhães et al., 2010, 2014; Cogné et al., 2011, 2013). Cogné et al. (2011, 2013) suggested that plate-wide compressional stresses reactivated the margin and guided uplift. However, the asymmetric, sharp, seaward-facing escarpments (Fig. 16) are associated with tilted hinterlands commonly planed by remnant erosional surfaces (e.g., Zalán \& Oliveira, 2005). Such faulted escarpment geomorphology points strongly towards footwall uplift (e.g., Burbank \& Anderson, 2001) at the km scale. Indeed, Zalán \& Oliveira (2005) interpreted a wide swath of Southeast Brasil to be the end product of post-breakup NW-SE-directed extension.

Strike-slip or high-angle faults that could be invoked to have facilitated footwall uplift are plentiful throughout the southeast Brasilian proximal domain. Baudon \& Cartwright (2008) recorded Cenozoic normal reactivation of a series of faults in the near-shore portion of the Espírito Santo basin. Ferrari (2001) documented NWSE-directed extension between Early and Late Oligocene time in the Guanabara graben. Gontijo-Pascutti et al. (2010) described dip-slip and strike-slip reactivation of Precambrian fabrics in the neighboring Rio Santana graben that began in the Paleogene and continued until 
at least the Quaternary. The $170 \mathrm{~km}$-long, $20 \mathrm{~km}$-wide, NE-SW-trending Taubaté graben (Fig. 16) is aligned with Precambrian Ribeira Belt structural trends, parallels the faulted, uplifted range front escarpment of the Serra da Mantiqueira, and contains Upper Oligocene to Eocene sedimentary rocks that are themselves cross-cut by normal faults (Padilha et al., 1991). The authors of a recent geomorphic analysis of summit surfaces in the Serra do Mar (Aires et al., 2012) proposed that $\mathrm{km}$-scale normal faulting occurred during the Cenozoic. As in Scandinavia, the present-day stress field in much of Southeast Brasil is generally considered slightly compressive (Riccomini et al., 1989; Riccomini \& Assumpção, 1999; Salomon et al., 2014). However, landscapes and neotectonic deformation that include components of normal faulting are also well documented (e.g., Riccomini et al., 1989; Riccomini \& Assumpção, 1999; Bezerra \& Vita-Finzi, 2000; Fortes et al., 2005; Gontijo-Pascutti et al., 2010; Silva \& Mello, 2011). In Northeast Brasil, neotectonic faulting caused systematic uplift and subsidence that may have been largely responsible for shaping today's landscapes (Bezerra et al., 2006, 2008, 2014).

Although the Brasilian escarpments were not incised by post-breakup glacial erosion, Neogene sedimentary thicknesses in parts of Pelotas, Santos, and Campos basins range between 0.5 to perhaps more than $2 \mathrm{~km}$ (Modica \& Brush, 2004; Assumpção et al., 2011; Contreras, 2011). The load is applied atop very thin crust (Mohriak et al., 2010; Assumpção et al., 2011; Zalán et al., 2011; Mohriak \& Leroy, 2012). A diffuse belt of seismicity occurs near or beyond the Cretaceous hinge line (Fig. 16) where the continental crust becomes highly extended (Assumpção, 1998; Assumpção et al., 2011, 2014; see maps by Assumpção et al., 1997, 2011, Zalán \& Oliveira, 2005; Zalán et al., 2011). Several of its earthquakes were characterized by compressional focal-plane mechanisms and had well-located hypocenters that indicated middle or upper crustal depths (Assumpção et al., 2011). Invoking a crust severely weakened by Mesozoic extension, recent deformation by thick sedimentary loads, and compressive and tensile flexural bending stresses separated both by a neutral surface and the theoretical peripheral bulge, Assumpção et al. (2011) explicitly proposed a very similar conceptual model to explain the 2008 São Vicente offshore earthquake and related earthquakes of the southeast Brasilian continental shelf seismic zone.

Because the datasets needed to properly map the TB are not in the public domain, we are at this point unable to formally test relationships between Brasilian taper, topography, and earthquakes. However, we suspect that certain parts of our hyperextension-based conceptual model for Scandinavian seismogenesis and post-breakup topographic rejuvenation will also apply to the southeast Brasilian margin. We point especially towards what can be interpreted as an onshore escarpment erected by postbreakup footwall uplift (citations above) and the diffuse belt of offshore seismicity described by Assumpção et

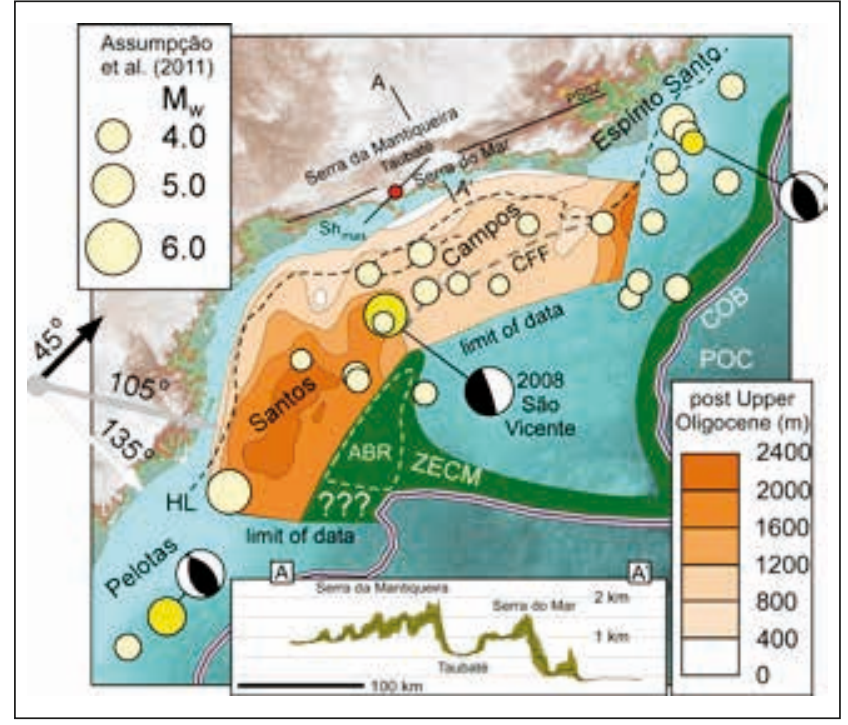

Figure 16. Map following Assumpção et al. (2011, 2014), showing earthquake epicenters of the offshore seismic zone and one onshore $\mathrm{Sh}_{\max }$ measurement from Southeast Brasil. Bright yellow epicenters represent events associated with the accompanying beach ball diagrams. Zone of Exhumed Continental Mantle (ZECM) and Continent Ocean Boundary (COB) follow the offshore interpretation of Zalán et al. (2011). HL - Cretaceous hinge line, ABR - Abimael Ridge, CFF - Cabo Frio Fault, POC - Penrose Oceanic Crust, PSSZ - Paraíba do Sul Shear Zone. Rio Santana and Guanabara grabens mentioned in the text lie between the Taubaté basin and the Serra do Mar. Post-Upper Oligocene sedimentary thicknesses after Assumpção et al. (2011). Topographic profile A-A' made with DEM data from Smith \& Sandwell (1997). Vector decomposition describing initial stretching direction prior to breakup from Zalán \& Oliveira (2005) and Almeida et al. (2013).

al. (2011) that in our opinion is directly equivalent to Scandinavia’s SB1 (Figs. 1, 16).

\section{Concluding remarks}

Observing the oblique, seaward-facing nature of the Norwegian highlands, Holtedahl (1953) suggested that Scandinavia's uplift was facilitated by faults bordering the coastline. Torske (1972) described Norwegian topography in terms of a Red Sea style rift shoulder related to Early Eocene opening of the North Atlantic. Doré (1992) coined the term 'Base Tertiary Surface' to describe a single, firstorder, low-relief landscape that incorporates previously existing unconformities, has been extensively modified since its formation, and can potentially be correlated from offshore to onshore.

These ideas were prescient. The faults postulated by Holtedahl (1953) are known to exist; many were active across much of the onshore proximal domain during the Late Mesozoic (Redfield et al., 2004, 2005b; Osmundsen et al., 2009, 2010; Hendriks et al., 2010; Davids et al., 2013; Indrevær et al., 2013; Ksienzyck et al., 2014; Torgersen et al., 2014). Some are very likely to have undergone postlatest Cretaceous, normal-sense reactivation (op. cit.). The 
oblique to tensional focal-plane mechanisms recovered from the Norwegian escarpment (Hicks et al., 2000) indicate onshore and near-shore normal faulting is active today. Although the large-magnitude crustal extension that formed the rift shoulder proposed by Torske (1972) is now considered to have occurred in latest Jurassic to Early Cretaceous time (see Osmundsen \& Ebbing, 2008 and citations therein), post-Early Eocene footwall uplift appears to have been responsible for the greater part of Scandinavia's asymmetric topography. The connection of offshore unconformities to onshore counterparts remains hampered by our fundamental inability to either accurately determine the age of formation of Scandinavia's paleosurfaces or to correlate between them. Similar highelevation surfaces do cross-cut Cenozoic volcanic rocks that were originally extruded at or just below sea level in East Greenland (Bonow et al., 2014), recording beyond doubt similar events of post-breakup uplift and erosion of Scandinavia's conjugate margin. Nevertheless, there is little geological consensus as to how post-breakup mountains can rise on a rifted margin.

Osmundsen \& Redfield (2011) and Redfield \& Osmundsen (2013) documented the long-term tectonic importance of the crustal thinning gradient to the onshore topographic envelope of the rifted margin. The critical benchmark is the Taper Break (TB), the zone of transition to the hyperextended distal domain. In the beginning of this paper we refined our location of the Scandinavian TB using recently published seismic refraction and potential field data (Figs. 3, 4, 5). We also demonstrated that whilst alternative geoseismic interpretations can be made, they do not significantly impact the TB or the Taper Hypothesis (Fig. 6). Our latest mapping interprets the TB as a marginscale mega-relay, the offshore complement to the MøreTrøndelag Fault Complex (MTFC) mega-relay that separates the southern from the northern Scandinavian Mountains. We consider this a structural pattern rife with geotectonic ramifications that, as yet, remain underexplored.

In the second part of this paper we documented a direct spatial correlation between three discrete belts of earthquakes and the boundaries of three elemental domains of the Scandinavian extended margin. We quantified the energy release of the belts by computing their Cumulative Seismic Moment $\left(\mathrm{CSM}_{\mathrm{w}}\right)$ energy (Fig. 7). We observed that the distribution of $\mathrm{CSM}_{w}$ energy is asymmetric. Although large earthquakes occur all across Fennoscandia, some $80 \%$ of $\mathrm{CSM}_{w}$ is expended on the Scandinavian rifted margin, here defined as the extended margin and its hinterland (Figs. 2, 7, 10). We also showed that although rapid and recent sedimentation is a fundamental cause of offshore stress, previous structural preparation is required to maximize seismogenesis of the outer belt (SB1; Figs. 12, 13). CSM ${ }_{w}$ per unit area is greatest where the crust is at its thinnest, the underlying continental mantle is at least partially compromised by brittle faulting, and could possibly be serpentinized to an unknown depth - in effect, at the TB. Our results indicate that the TB functions as a permanently weakened zone that responds seismically if stress relaxation cannot keep pace with the incoming sedimentary load.

In the last part of this paper we developed a conceptual seismological model that places Fennoscandian seismicity firmly within the context of some new concepts for rifted margin formation (e.g., Manatschal, 2004; PéronPinvidic et al., 2013). Our model (Fig. 15) couples the assumption that the state of stress in the upper crust can be approximated by simple and time-honoured (Gunn, 1943; Vening Meinesz, 1950; Walcott, 1972) flexed thinplate theory to the recognition by Lima et al. (1997), Bezerra \& Vita-Finzi (2000), Byrkeland et al. (2000), Assumpção et al. (2011), and many others that geologically rapid onshore erosion and offshore deposition can have a significant seismogenic effect on a rifted margin. Our model predicts relatively deep and compressive events in the offshore belt and shallower, more tensile events in the near-shore proximal domain, accurately reflecting the generalized depth partitioning observed in Nature (Hicks et al., 2000). It explains why the observed belts of concentrated seismicity correlate with boundaries between the fundamental domains of the Mesozoic-Paleogene extended margin, predicts the intervening seismic gaps, and places the outboard-to-inboard decay of $\mathrm{CSM}_{w}$ (Fig. 10) into a simple, flexed thin-plate tectonic framework. It qualitatively links the sharpness of crustal taper with the amount of near-shore $\mathrm{CSM}_{\mathrm{w}}$ energy expenditure and the likelihood of localized, normal-fault footwall uplift and landscape rejuvenation. It incidentally provides a plausible and internally consistent explanation for the paucity of TB seismicity along the currently glaciated East Greenland conjugate rifted margin. Ice loading and land surface suppression would be expected to generate a flexural tensile bulge at the $\mathrm{TB}$ with bending stresses that partially or even completely overprint the compressive effect of the downward deflection by sediment loading.

Although the mean Plio-Pleistocene sedimentary thickness deposited at the TB offshore southern/Mid Norway is $\sim 1 \mathrm{~km}$ less than that of the BØF, more than twice as much $\mathrm{CSM}_{\mathrm{w}}$ energy is released from the thinned continental crust as from the oceanic domain (Figs. 12, 13). Our model explains the difference by proposing that the necked and faulted subcontinental lithosphere in the area of the TB depocenters is significantly weaker than the relatively young ( $53-55 \mathrm{Ma}$; see Lundin \& Doré, 1997) oceanic lithosphere underlying much of the $\mathrm{B} \varnothing \mathrm{F}$. This interpretation runs counter to the commonly invoked hypothesis that post-thinning cooling increases the lithospheric strength of highly-extended margin domains (e.g., Kusznir \& Park, 1987; Ziegler \& Cloetingh, 2004). Instead, our interpretation supports the proposal that where its crust is not stiffened by volcanic intrusions, much of the distal domain can remain weak despite cooling (see citations in The extended margin, above). Were other un-stiffened parts of the distal domain also 
loaded rapidly and recently, it seems likely they too could be seismic prior to stress relaxation. A parallel implication of our observations and interpretations is that far-field forces may perhaps not be able to propagate very deeply into a hyperextended continental margin. The resolution of contrasting oceanward-directed continental and landward-directed oceanic GPE against the TB and the hyperextended distal domain may perhaps ultimately localize as oceanic-continent subduction (e.g., Masson et al., 1994; Faccenna et al., 1999; Péron-Pinvidic et al., 2008; Marques et al., 2013; Redfield \& Osmundsen, 2013).

Our model competes against the genres that cite NWSE-directed maximum horizontal stresses $\left(\mathrm{Sh}_{\max }\right)$ as evidence that Fennoscandia's earthquakes are caused largely by far-field plate boundary forces. Concerned by the general absence of seismicity throughout the seaward domains excepting those areas subjected to recent and rapid vertical loads, we prefer to interpret flowlineparallel $\mathrm{Sh}_{\max }$ data by noting that because the strike of the Norwegian Sea TB is similar to the Mid-Atlantic spreading ridge, $\mathrm{Sh}_{\max }$ due to thin-plate flexure and compressive bending stress will be oriented largely in the direction of plate tectonic transport. Our model predicts the onset of weak compressional bending stresses in the hinterland inflection to landward of SB2, becoming progressively stronger towards the HBSL and the craton. This predicted stress field could readily be mistaken for ridge push. Small stress tensor deviations observed in offshore well data or in situ outcrop measurements (e.g., Pascal et al., 2010) may be the products of subtle variations in basin geometry or topography.

Fennoscandia's self-organization into discrete seismic zones of diminishing CSM $\mathrm{w}_{\mathrm{w}}$ energy intensity (Fig. 10) implies to us that, in terms of earthquake generation within the intra-plate continental crust, local stresses that impact important tectonic boundaries are much more important than far-field horizontal (e.g., plate tectonic) stresses. This self-organization has led to postbreakup normal sense reactivation of favorably located and favorably oriented pre-existing faults such as the MTFC, the Main Lyngen Fault, and the Hadselfjorden Fault Zone in Sortlandsundet (Fig. 14). A rejuvenated faulted topography exhibiting uplifted footwall ranges and a marked topographic/landscape contrast between their footwalls and hanging walls is the final product of the Norwegian margin's sharply tapered sectors. Because many of the observations and interpretations which underpin our conceptual model have been made elsewhere (e.g., Assumpção et al., 2011; Zalán et al., 2011), we reiterate our suggestion (Osmundsen \& Redfield, 2011) that the sharpness of crustal taper may be the most important condition that governs the post-breakup evolution of rifted margins.

In the sections above we have presented evidence for what amounts to a new, conceptual seismological system for the generalized hyperextended margin. A truly quantitative test of the system is for the future; it remains challenging to construct a time-space numerical test that can honour the Earth's inherent inhomogeneity yet is still able to expose the basic physical principles that cause earthquakes within stable continental regions and their neighboring rifted margins. It is extremely difficult to adequately constrain fundamental parameters such as the effective elastic response of, and the finite load imposed on, even a two-dimensional natural rock beam. Furthermore, the concept of an entire continental margin being composed of a single homogeneous rock mass that responds over vast horizontal distances to stress (or anything else) in a textbook fashion is completely foreign to field-based structural geologists. All models are wrong (Box \& Draper, 1987) and we accept that ours must be too - but we hope it is not so wrong that its concepts cannot prove useful. We posit the generic hyperextended, postbreakup rifted margin to be characterized by long-term adjustments to a constantly evolving stress regime driven principally by lithospheric flexure in response to erosion and sedimentary loading - a penultimate accommodation phase prior to destruction by subduction at the end of the Wilson Cycle.

Acknowledgements. The ideas presented in this paper were inspired by many years of discussions with colleagues from NGU and other institutions. Comments by R. H. Gabrielsen and an anonymous reviewer greatly improved the original manuscript - especially those bits on seismology as originally written by these two non-seismologists. Prof. Tracy K.P. Gregg kindly provided important components of Fig. 15. This is an NGU product. Internal financial support was provided by projects 051242, 051220, 349100, 347300, and Project X..

\section{References}

Agricola, G. 1556: Bermannus, sive de metallica (translated as De Re Metallica by President of the United States H.C. Hoover \& First Lady of the United States L. Hoover). Dover Publications, New York, $638 \mathrm{pp}$.

Ahjos, T. \& Uski, M. 1992: Earthquakes in Northern Europe in 13751989, Tectonophysics 207, 1-23.

Ahlmann, H.W. 1919: Geomorphological studies in Norway. Geografisk Annaler 1-2, 1-252.

Aires, J.R., Motoki, A., Motoki, K.F., Motoki, D.F. \& Rodrigues, J.G. 2012: Análises Geomorfológicas do Platô de Teresópolis e da Serra do Mar, RJ, com o Auxílio de Seppômen e ASTER GDEM e sua Relação aos Tectonismos Cenozoicos. Anuário do Instituto de Geociências - UFRJ 35, 105-123.

Almeida , J. Dios, F., Mohriak, W.U., Valeriano, C.D.M., Heilbron, M., Eirado, L.G. \& Tomazzoli, E. 2013: Pre-rift tectonic scenario of the Eo-Cretaceous Gondwana break-up along SE Brazil-SW Africa: insights from tholeiitic mafic dyke swarms. Geological Society of London Special Publications 369, 11-40.

Amos, C.B., Audet, P., Hammond, W.C., Burgmann, R., Johanson, I. \& Blewitt, G. 2014: Uplift and seismicity driven by groundwater depletion in central California. Nature 509, 483-486.

Andersen, O.B., Knudsen, P. \& Berry, P. 2010: The DNSC08GRA global marine gravity field from double retracked satellite altimetry. Journal of Geodesy 84, 191-199.

Arvidsson, R. 1996: Fennoscandian earthquakes: whole crustal rupturing related to postglacial rebound. Science 274, 744-746. 
Assumpção, M. 1992: The regional intraplate stress field in South America. Journal of Geophysical Research 97, 11,889-11,903.

Assumpção, M. 1998: Seismicity and stresses in the Brazilian passive margin. Bulletin of the Seismological Society of America 88, 160-169.

Assumpção, M., Barbosa, J.R., Berrocal, J., Bassini, A.M., Veloso, J.A.V., Mârza, V.I., Huelsen, M.G., \& Ribotta, L.C. 1997: Seismicity patterns and focal mechanisms in southeastern Brazil. Revista Brasileira de Geofísica 15, 15-30.

Assumpção, M., Dourado, J.C., Robotta, L.C., Mohriak, W.U., Dias, F.L. \& Barbossa, J.R. 2011: The São Vicente earthquake of 2008 April and seismicity in the continental shelf off SE Brazil: further evidence for flexural stresses. Geophysical Journal International 187, 1076-1088.

Assumpção, M., Ferreira, J., Barros, L., Bezerra, F.H., França, G.S., Barbosa, J.R., Menezes, E., Ribotta, L.C., Pirchiner, M., Nascimento, A. \& Dourado, J.C. 2014: Intraplate Seismicity in Brazil. In Talwani P. (ed.): Intraplate Earthquakes, Cambridge University Press, pp. 50-71.

Bassin, C., Laske, G. \& Masters, G. 2000: The current limits of resolution for surface wave tomography in North America. Abstracts and Proceedings, EOS, Transactions American Geophysical Union 81, 897.

Bauck, M.S. 2010: Fault rock assemblages and fault architecture in the Møre-Trøndelag Fault Complex. M.S. thesis, Norwegian University of Science and Technology, Trondheim, $97 \mathrm{pp}$.

Baudon, C. \& Cartwright, J. 2008: The kinematics of reactivation of normal faults using high resolution throw mapping. Journal of Structural Geology 30, 1072-1084.

Baumgardner, J.R. \& Frederickson, P.O. 1985: Icosahedral discretization of the twosphere. Society for Industrial and Applied Mathematics Journal of Numerical Analysis 22, 1107-1115.

Bezerra, F.H.R. \& Vita-Finzi, C. 2000: How active is a passive margin? Paleoseismicity in northeastern Brazil. Geology 28, 591-594.

Bezerra, F.H.R., Ferreira, J. \& Sousa, M.O.M. 2006: Review of seismicity and Neogene tectonics in northeastern Brazil. Revista de la Asociación Geológica Argentina 61, 525-535.

Bezerra, F.H.R., Brito Neves, B.B., Corrêa, A.C.B., Barreto, A.M.F. \& Suguio, K. 2008: Late Pleistocene tectonic-geomorphological development within a passive margin - The Cariatá trough, northeastern Brazil. Geomorphology 97, 555-582.

Bezerra, F.H.R. Rossetti, D.F. Oliveira, R.G. Andrades Filho, C. \& Góes, A.M. 2014: Neotectonic reactivation of shear zones and implications for faulting style and geometry in the continental margin of NE Brazil. Tectonophysics 614, 78-90.

Blystad, P., Brekke, H., Færseth, R.B., Larsen, B.T., Skogseid, J. \& Tørudbakken, B. 1995: Structural Elements of the Norwegian Continental Shelf. Part II: The Norwegian Sea Region. Norwegian Petroleum Directorate Bulletin 8, 1-45.

Bodine, J.H., Steckler, M.S. \& Watts, A.B. 1981: Observations of flexure and the rheology of the ocean lithosphere. Journal of Geophysical Research 86, 3695-3707.

Bonow, J.M., Japsen. P. \& Nielsen, T.F.D. 2014: High-level landscapes along the margin of southern East Greenland - A record of tectonic uplift and incision after breakup in the NE Atlantic. Global and Planetary Change 116, 10-29.

Bott, M.H.P. 1991: Ridge push and associate plate interior stress in normal and hot spot regions. Tectonophysics 200, 17-32.

Box, G.E.P. \& Draper N.R. 1987: Empirical Model-Building and Response Surfaces. John Wiley and Sons, New York, 424 pp.

Breivik, A.J., Mjelde, R., Raum, T., Faleide, J.I., Murai, Y. \& Flueh, E.R. 2011: Crustal structure beneath the Trondelag Platform and adjacent areas of the Mid-Norwegian margin, as derived from wide angle seismic and potential field data. Norwegian Journal of Geology 90, 141-161.

Brekke, H. 2000: The tectonic evolution of the Norwegian Sea continental margin, with emphasis on the Vøring and Møre basins. In Nøttvedt, A., Brekke, H. \& Birkeland, Ø. (eds.): Dynamics of the Norwegian Margin, Geological Society, London, Special Publications 167, pp. 327-378.
Bungum, H., Lindholm, C. \& Faleide, J.I. 2005: Postglacial seismicity offshore mid-Norway with emphasis on spatiotemporalmagnitudal variations. Marine and Petroleum Geology 22, 137-148.

Bungum, H., Olesen, O., Pascal, C., Gibbons, S., Lindholm, C., \& Vestol, O. 2010: To what extent is the present seismicity of Norway driven by post-glacial rebound? Journal of the Geological Society of London $167,373-384$

Burbank, D. \& Anderson, R. 2001: Tectonic Geomorphology. Blackwell Publishing, Malden, MA, 274 pp.

Byrkeland, U, Bungum, H., \& Eldholm, O. 2000: Seismotectonics of the Norwegian continental margin. Journal of Geophysical Research $105,6221-6236$.

Böðvarsson, R., Lund, B., Roberts, R. \& Slunga, R. 2006: Earthquake activity in Sweden - a study in connection with a proposed nuclear waste repository in Forsmark or Oskarshamn. Svensk Kärnbränslehantering AB Report R-06-67, 40 pp.

Bøe, R., Fossen, H. \& Smelror, M. 2010: Mesozoic sediments and structures onshore Norway and in the coastal zone. Norges geologiske undersøkelse Bulletin 450, 15-32.

Chase, C., \& Wallace, T. 1988: Flexural Isostasy and uplift of the Sierra Nevada of California. Journal of Geophysical Research 93, 27952802.

Christensen, D. \& Ruff, L. 1988: Seismic coupling and outer rise earthquakes. Journal of Geophysical Research 93, 13,421-13,444.

Cogné, N., Gallagher, K. \& Cobbold, P.R. 2011: Post-rift reactivation of the onshore margin of southeast Brazil: Evidence from apatite (U-Th)/He and fission-track data. Earth and Planetary Science Letters 309, 118-130.

Cogné, N., Cobbold, P.R., Riccomini, C. \& Gallagher, K. 2013: Tectonic setting of the Taubaté Basin (Southeastern Brazil): Insights from regional seismic profiles and outcrop data. Journal of South American Earth Sciences 42, 194-204.

Conference Participants 1972: Penrose Field Conference: Ophiolites. Geotimes 17, 24-25.

Contreras, J. 2011: Seismo-stratigraphy and numerical basin modeling of the southern Brazilian continental margin (Campos, Santos, and Pelotas basins). Ph.D. Thesis, University of Heidelberg, $171 \mathrm{pp}$.

Davids, C., Wemmer, K., Zwingmann, H., Kohlmann, F., Jacobs, J. \& Bergh, S.G. 2013: K-Ar illite and apatite fission track constraints on brittle faulting and the evolution of the northern Norwegian passive margin. Tectonophysics 608, 196-211.

Davidsen, B., Somaruga, A. \& Bøe, R. 2001: Sedimentation, tectonics and uplift in Vesterålen; Phase 1: Localizing near-shore faults and Mesozoic sediment basins. Geological Survey of Norway Report 2001.111, 16 pp.

Densmore, A., Dawers, N., Gupta, S., Guidon, R. \& Goldin, T. 2004: Footwall topographic development during continental extension. Journal of Geophysical Research, Earth Surface 109, 6221-6236.

Dilek, Y. 2003: Ophiolite concept and its evolution. Geological Society of America Special Paper 373, 16 pp.

Doré, A.G. 1992: The Base Tertiary Surface of southem Norway and the northern North Sea. Norwegian Journal of Geology 72, 259-265.

Ebbing, J. \& Olesen, O. 2010: New compilation of top basement and basement thickness for the Norwegian continental shelf reveals segmentation of the passive margin system. Petroleum Geology Conference Series 7, 885-897.

Ebbing, J., Lundin, E., Olesen, O. \& Hansen, E.K. 2006: The midNorwegian margin: a discussion of crustal lineaments, mafic intrusions, and remnants of the Caledonian root by 3D density modelling and structural interpretation. Journal of the Geological Society of London 163, 47-59.

Ebbing, J., England, R.W., Korja, T., Lauritsen, T., Olesen, O., Stratford, W. \& Weidle, C. 2012: Structure of the Scandes lithosphere from surface to depth. Tectonophysics 536-537, 1-24.

Etzelmüller, B., Romstad, B. \& Fjellanger, J. 2007: Automatic regional classification of topography in Norway. Norwegian Journal of Geology 87, 167-180. 
Faccenna, C., Giardini, D., Davy, P. \& Argentieri, A. 1999: Initiation of subduction at Atlantic type margins: Insights from laboratory experiments. Journal of Geophysical Research 104, 2749-2766.

Faleide, J.I., Kyrkjebø, R., Kjennerud, T., Gabrielsen, R.H., Jordt, H., Fanavoll, S. \& Bjerk, M.D. 2002: Tectonic impact on sedimentary processes during Cenozoic evolution of the northern North Sea and surrounding areas. In Doré, A.G., Cartwright, J.A., Stoker, M.S., Turner, J.P. \& White, N.J. (eds.): Exhumation of the North Atlantic Margin; Timing, Mechanisms and Implications for Petroleum Exploration, Geological Society of London Special Publications 196, pp. 235-269.

Faleide, J.I., Tsikalas, F., Breivik, A.J., Mjelde, R., Ritzmann, O., Engen, Ø., Wilson, J. \& Eldholm, O. 2008: Structure and evolution of the continental margin off Norway and the Barents Sea. Episodes 31, 82-91.

Fejerskov, M. \& Lindholm, C.D. 2000: Crustal stress in and around Norway; an evaluation of stress-generating mechanisms. In Nottvedt. A. (ed.): Dynamics of the Norwegian margin, Geological Society of London Special Publications 167, pp. 451-467.

Ferrari, A.L, 2001: Evolução Tectônica do Graben da Guanabara. Ph.D. thesis, Universidade de São Paulo, 412 pp.

Fiedler, A \& Faleide, J.I. 1996: Cenozoic sedimentation along the southwestern BarentsSea margin in relation to uplift and erosion of the shelf. Global and Planetary Change 318, 75-93.

Fortes, E., Stevaux, J. \& Volkmer, S. 2005: Neotectonics and channel evolution of the Lower Ivinhema River: A right-bank tributary of the upper Paraná River, Brazil. Geomorphology 70, 325-338.

Franco-Magalhães, A.O.B., Hackspacher, P.C., Glasmacher, U.A., \& Saad A.R. 2010: Rift to post-rift evolution of a "passive" continental margin: the Ponta Grossa Arch, SE Brazil. International Journa of Earth Science (Geologische Rundschau) 99, 599-1613.

Franco-Magalhães, A.O.B., Cuglieri, M.A.A., Hackspacher, P.C. \& Saad, A.R. 2014: Long-term landscape evolution and post-rift reactivation in the southeastern Brazilian passive continental margin: Taubaté basin. International Journal of Earth Science (Geologische Rundschau) 103, 441-453.

Fürsich, F.T. \& Thomsen, E. 2005: Jurassic biota and biofacies in erratics from the Sortland area, Vesterålen, northern Norway. Norges geologiske undersøkelse Bulletin 443, 37-53.

Færseth, R.B. \& Lien, T. 2002: Cretaceous evolution in the Norwegian Sea; a period characterized by tectonic quiescence. Marine and Petroleum Geology 19, 1005-1027.

Gaál, G. \& Gorbatschev, R. 1987: An outline of the Precambrian evolution of the Baltic Shield. Precambrian Research 35, 15-52.

Gabrielsen, R.H., Faleide, J.I., Pascal, C., Braathen, A., Nystuen, J.-P., Etzelmuller, B. \& O’Donnell, S. 2010: Latest Caledonian to Present tectonomorphological development of southern Norway. Marine and Petroleum Geology 27, 709-723.

Gallagher, K. Hawkesworth, C.J. \& Mantivani, M.S.M. 1994: The denudation history of the onshore continental margin of SE Brazil inferred from apatite fission track data. Journal of Geophysical Research: Solid Earth 99, 18117-18145.

Gawthorpe, R.L. \& Leeder, M.R.. 2000: Tectono-sedimentary evolution of active extensional basins. Basin Research 12, 195-218

Gilchrist, A.R., \& Summerfield, M.A. 1990: Differential denudation and flexural isostasy in formation of rifted-margin upwarps. Nature 346, 739-742.

Gjessing, J. 1967: Norway's paleic surface. Norwegian Journal of Geology 21, 69-132.

Gomez, M., Verges, J., Fernandez, M., Torne, M., Ayala, C., Wheeler, W. \& Karpuz, R. 2004: Extensional geometry of the mid Norwegian margin before early Tertiary continental breakup. Marine and Petroleum Geology 21, 177-194.

Gontijo-Pascutti, A., Bezerra, F.H.R., La Terra, E. \& Almeida, J. 2010: Brittle reactivation of mylonitic fabric and the origin of the Cenozoic Rio Santana Graben, southeastern Brazil. Journal of South American Earth Sciences 29, 522-536.
Grollimund, B. \& Zoback, M.D. 2001: Did deglaciation trigger intraplate seismicity in the New Madrid seismic zone? Geology 29, 175-178.

Grollimund, B. \& Zoback, M.D. 2003: Impact of glacially-induced stress changes on fault seal integrity offshore Norway. American Association of Petroleum Geologists Bulletin 87, 493-506.

Gudmundsson, A. 1999: Postglacial crustal doming, stresses and fracture deformation with application to Norway. Tectonophysics 307, 407-419.

Gunn, R. 1943: A quantitative evaluation of the influence of the lithosphere on the anomalies of gravity. Journal of the Franklin Institute 236, 47-65.

Gunnell, Y. \& Fleitout, L. 1998: Shoulder uplift of the western Ghats passive margin, India: a denudational model. Earth Surfaces Processes and Landforms 23, 391-404.

Gunnell, Y. \& Harbor, D. 2010: Butte detachment: where pre-rift geologic structure and drainage integration drive escarpment evolution at rifted continental margins. Earth Surface Processes and Landforms 35, 1373-1385.

Hall, A.M., Ebert, K., Klemen, J., Nesje, A. \& Ottesen, D. 2013: Selective glacial erosion on the Norwegian passive margin. Geology 41, 1203-1206.

Hendriks, B.W.H. \& Redfield, T.F. 2005: Apatite fission track and $(\mathrm{U}-\mathrm{Th}) / \mathrm{He}$ data from Fennoscandia: An example of underestimation of fission track annealing in apatite. Earth and Planetary Science Letters 236, 443-458.

Hendriks, B.W.H. \& Redfield, T.F. 2006: Reply to: Comment on Apatite Fission Track and (U--Th)/He data from Fennoscandia: An example of underestimation of fission track annealing in apatite. Earth and Planetary Science Letters 248, 568-576.

Hendriks, B.W.H., Andriessen, P., Huigen, Y., Leighton, C., Redfield, T., Murrell, G., Gallagher, K. \& Nielsen, S.B. 2007: A Fission Track Data Compilation for Fennoscandia. Norwegian Journal of Geology 87, 143-155.

Hendriks, B.W.H., Osmundsen, P.T. \& Redfield, T.F. 2010: Normal faulting and block tilting in Lofoten and Vesterålen constrained by apatite fission track data. Tectonophysics 485, 154-163.

Hicks, E., Bungum, H. \& Lindholm, C. 2000: Stress inversions of earthquake focal mechanism solutions from onshore and offshore Norway. Norwegian Journal of Geology 80, 235-250.

Hjelstuen B.O. 1997: The Cenozoic Vøring and Barents Sea continental margins. Dr. scient. thesis, Department of Geology, University of Oslo, $401 \mathrm{pp}$.

Hjelstuen, B.O., Elverhøi, A. \& Faleide, J.1. 1996: Cenozoic erosion and sediment yield in the drainage area of the Stortjorden Fan. Global and Planetary Change 12, 95-117.

Holtedahl, H. 1953: On the oblique uplift of some northern lands. Norwegian Journal of Geology 14, 132-139.

Indrevær, K., Bergh, S.G., Koehl, J.-B., Hansen, J.-A., Schermer, E.R. \& Ingebrigtsen, A. 2013: Post-Caledonian brittle fault zones on the hyperextended SW Barents Sea margin: New insights into onshore and offshore margin architecture. Norwegian Journal of Geology 93, 167-188.

Jaeger, J.C., Cook, N.G.W. \& Zimmerman, R.W. 2007: Fundamentals of Rock Mechanics. Fourth Edition. Blackwell Publishing Ltd, Malden, Maryland, $475 \mathrm{pp}$.

Japsen, P. 1998: Regional Velocity-Depth Anomalies, North Sea Chalk: A Record of Overpressure and Neogene Uplift and Erosion. American Association of Petroleum Geologists Bulletin 82, 20312074.

Japsen, P., Bonow, J. M., Green, P. F., Cobbold, P. R., Chiossi, D., Lilletveit, R., Magnavita, L. P., \& Pedreira, A. J. 2012a: Episodic burial and exhumation history of NE Brazil after opening of the South Atlantic. Geological Society of America Bulletin 124, 800-816.

Japsen, P., Chalmers, J. A., Green, P. F., \& Bonow, J. M. 2012b: Elevated, passive continental margins: Not rift shoulders but expressions of episodic, post-rift burial and exhumation. Global and Planetary Change 90-91, 73-86. 
Johannessen, K.C., Kohlmann, F., Ksienzyk, A.K., Dunkl, I. \& Jacobs, J. 2013: Tectonic evolution of the SW Norwegian passive margin based on low temperature thermochronology from the innermost Hardangerfjord area. Norwegian Journal of Geology 93, 243-260.

Johnston, A.C. \& Kanter, L.R. 1990: Earthquakes in stable continental crust. Scientific American 262, 42-49.

Kinck, J.J., Husebye, E.S. \& Larsson, F.R. 1993: The Moho depth distribution in Fennoscandia and the regional tectonic evolution from Archean to Permian times. Precambrian Research 64, 23-51.

Klemperer, S.L., Hauge, T.A., Hauser, E.C., Oliver, J.E. \& Potter, C.J. 1986: The Moho in the northern Basin and Range, Nevada, along the COCORP $40 \mathrm{~N}$ seismic-reflection transect. Geological Society of America Bulletin 97, 603-618.

Ksienzyk, A.K., Dunkl, I., Jacobs, J, Fossen, H. \& Kohlmann, F. 2014: From orogen to passive margin: Constraints from fission track and (U-Th)/he analyses on Mesozoic uplift and fault reactivation in SW Norway. In Corfu, F., Gasser, D. Chew, D.M. (eds.): New Perspectives on the Caledonides of Scandinavia and Related Areas, Geological Society of London Special Publications 390, pp. 679-702.

Kusznir, N.J. \& Park, R.G. 1987: The extensional strength of the continental lithosphere: its dependence on geothermal gradient, and crustal composition and thicknes. In Coward, M.P., Dewey, J.F. \& Hancock, P.L. (eds.): Continental Extensional Tectonics, Geological Society Special Publication 28, pp. 35-52.

Kusznir, N.J., Marsden G. \& Egan, S.S.1991: A flexural cantilever simple-shear/pure-shear model of continental lithosphere extension: application to the Jeanne d'Arc basin, Grand Banks and Viking Graben, North Sea. In Yielding, A.M. \& Freeman, B. (eds.): The Geometry of Normal Faults, Geological Society of London Special Publications 56, pp. 41-60.

Kvarven, T., Ebbing, J., Mjelde, R., Faleide, J.I., Libak, A., Thybo, H., Flueh, E.R. \& Murai, Y. 2014: Crustal structure across the Møre margin, mid-Norway, from wide-angle seismic and gravity data. Tectonophysics 626, 21-40.

Leeder, M.R. \& Gawthorpe, R.L. 1987: Sedimentary models for extensional tiltblock/ half-graben basins. In Coward, M.P., Dewey, J.F. \& Hancock, P.L. (eds.): Continental Extensional Tectonics, Geological Society of London Special Publications 28, pp. 139-152.

Leeder, M.A. \& Jackson, J.A. 1993: The interaction between normal faulting and drainage in active extensional basins, with examples from the western United States and central Greece. Basin Research $5,79-102$.

Lidmar-Bergström, K. 1999: Uplift histories revealed by landforms of the Scandinavian domes. In Smith, B.J., Whalley, W.B. \& Warke, P.A. (eds.): Uplift, Erosion and Stability: Perspectives on Long-term Landscape Development, Geological Society of London Special Publications 162, pp. 1-7.

Lidmar-Bergström, K., Ollier, C.D. \& Sulebak, J.R. 2000: Landforms and uplift history of Southern Norway. In Chalmers, J. \& Cloetingh, S.A.P.L. (eds.): Neogene uplift and tectonics around the North Atlantic, Global and Planetary Change 24, pp. 211-231.

Lima, C., Nascimento, E. \& Assumpcao, M. 1997: Stress orientations in Brazilian sedimentary basins from breakout analysis: implications for force models in the South American plate. Geophysical Journal International (Geologische Rundschau) 130, 112-124.

Ludwig, W.J., Ewing, J.I., Ewing, M., Murauchi, S., Den, N., Asano, S., Hotta, H., Hayakawa, M., Asanuma, T., Ichikawa, K. \& Noguchi, I. 1966: Sediments and structure of the Japan Trench. Journal of Geophysical Research 71, 2121-2137.

Lundin, E.R. \& Doré, A.G. 1997: A tectonic model for the Norwegian passive margin with implications for the NE Atlantic: early Cretaceous to break-up. Journal of the Geological Society London 154, 545-550.

Lundin, E.R. \& Doré, A.G. 2011: Hyperextension, serpentinization, and weakening: A new paradigm for rifted margin compressional deformation. Geology 39, 347-350.
Lundin, E.R., Redfield, T.F. \& Peron-Pindivic, G. 2014, Rifted continental margins: geometric influence on crustal architecture and melting, In Pindell, J., Horn, B., Rosen, N., Weimer, P., Dinkleman, M., Lowrie, A., Fillon, R., Granath, J. \& Kennian L. (eds.): Sedimentary basins: Origin, depositional histories, and petroleum systems, 33rd Annual GCSSEPM Foundation Bob F. Perkins Conference, pp. 18-53.

Løseth, H. \& Henriksen, S. 2005: A Middle to Late Miocene compression phase along the Norwegian passive margin. In Doré, A.G. \& Vining, B.A. (eds.): Petroleum geology: North-West Europe and global perspectives, Proceedings of the 6th petroleum geology conference, London: Geological Society, pp. 845-859.

Manatschal, G. 2004: New models for evolution of magma-poor rifted margins based on a review of data and concepts from West Iberia and the Alps. International Journal of Earth Science (Geologische Rundschau) 93, 432-466.

Manatschal, G., Froitzheim, N., Rubenach, M. \& Turrin, B.D. 2001: The role of detachment faulting in the formation of an ocean-continent transition: insights from the Iberia Abyssal Plain. In Wilson, R.C.L., Whitmarsh, R.B., Taylor, B. \& Froitzheim, N. (eds.): Non-volcanic rifting of continental margins: a comparison of evidence from land and sea, Geological Society of London, Special Publications 187, pp. $1-24$.

Marques, F., Nikoleva, K., Assumpção, M., Gerya, T.V., Bezerra, F.H.R., do Nascimento, A.F. \& Ferreira, J. M. 2013: Testing the influence of far-field topographic forcing on subduction initiation at a passive margin. Tectonophysics 608, 517-524.

Masson, D.G., Cartwright, J.A., Pinheiro, L.M., Whitmarsh, R.B., Beslier, M.O. \& Roeser, H. 1994: Compressional deformation at the continent-ocean transition in the NE Atlantic: Journal of the Geological Society of London 15, 607-613.

Matmon, A., Bierman, P. \& Enzel, Y. 2002: Pattern and tempo of great escarpment erosion. Geology 30, 1135-1138.

Mattila, J. \& Viola, G. 2014: New constraints on 1.7 Gyr of brittle tectonic evolution in southwestern Finland derived from a structural study at the site of a potential nuclear waste repository (Olkiluoto Island). Journal of Structural Geology 67, 50-74.

McKenzie, D. 1978: Some remarks on the development of sedimentary basins. Earth and Planetary Science Letters 40, 25-32.

Medvedev, S. \& Hartz, E.H. 2015: Evolution of topography of postDevonian Scandinavia: Effects and rates of erosion. Geomorphology 231, 229-245.

Mjelde, R., Shimamura, H., Kanazawa, T., Kodaira, S., Raum, T. \& Shiobara, H. 2003: Crustal lineaments, distribution of lower crustal intrusives and structural evolution of the Vøring margin, NE Atlantic; new insight from wide-angle seismic models. Tectonophysics 369, 199-218.

Modica, C.J. \& Brush, E.R. 2004: Postrift sequence stratigraphy, paleogeography, and fill history of the deep-water Santos Basin, offshore southeast Brazil. American Association of Petroleum Geologists Bulletin 88, 923-946.

Mohn, G., Manatschal, G., Müntener, O., Beltrando, M. \& Masini, E. 2010: Unravelling the interaction between tectonic and sedimentary processes during lithospheric thinning in the Alpine Tethys margins. International Journal of Earth Science (Geologische Rundschau) 99, 75-101.

Mohriak W. \& Leroy, S. 2012 : Architecture of rifted continental margins and break-up evolution: insights from the South Atlantic, North Atlantic and Red Sea-Gulf of Aden conjugate margins. In Mohriak, W.U., Danforth, A., Post, P.J., Brown, D.E., Tari, G.C., Nemcok, M. \& Sinha, S.T. (eds.): Conjugate Divergent Margins. Geological Society, London Special Publications 369, pp. 497-534.

Mohriak, W.U., Nóbrega, M. Odegard, M.E., Gomes, B.S. \& Dickson,W.G. 2010: Geological and geophysical interpretation of the Rio Grande Rise, south-eastern Brazilian margin: extensional tectonics and rifting of continental and oceanic crusts, Petroleum Geosciences 16, 231-245. 
Mosar, J. 2003: Scandinavia’s North Atlantic Passive Margin. Journal of Geophysical Research 108, 2360, doi: 10.1029/2002JB002134, B8.

Mosar, J., Lewis, G. \& Torsvik, T.H. 2002: North Atlantic sea-floor spreading rates: implications for the Tertiary development of inversion structures of the Norwegian-Greenland Sea. Journal of the Geological Society of London 159, 503-515.

Munier, R. \& Talbot, C.J. 1993: Segmentation, fragmentation and jostling of cratonic basement in and near Äspö, southeast Sweden. Tectonics 12, 713-727.

Nielsen, S.B., Gallagher, K., Leighton, C., Balling, N., Svenningsen, L., Jacobsen, B.H., Thomsen, E., Nielsen, O.B., Heilmann-Clausen, C. \& Egholm, D.L. 2009: The evolution of western Scandinavian topography: A review of Neogene uplift versus the ICE (isostasyclimate-erosion) hypothesis. Journal of Geodynamics 47, 72-95.

Nirrengarten, M., Gernigon, L. \& Manatschal, G. 2014: Lower Crustal Bodies in the Møre volcanic rifted margin: Geophysical determination and geological implications. Tectonophysics 636, 143-157.

Olesen, O., Bungum, H., Dehls, J., Lindholm, C., Pascal, C. \& Roberts, D. 2013: Neotectonics, seismicity and contemporary stress field in Norway - mechanisms and implications. In Olsen, L., Fredin, O. \& Olesen, O. (eds.): Quaternary Geology of Norway, Geological Survey of Norway Special Publication 13, pp. 145-174.

Olsen, L., Sveian, H., Ottesen, D. \& Rise, L., 2013: Quaternary glacial, interglacial and interstadial deposits of Norway and adjacent onshore and offshore areas. In Olsen, L., Fredin, O. \& Olesen, O. (eds.): Quaternary Geology of Norway, Geological Survey of Norway Special Publication 13, pp. 79-144.

Osmundsen, P.T. \& Ebbing, J. 2008: Styles of extension offshore Mid Norway and implications for mechanisms of crustal thinning at passive margins. Tectonics 27, TC6016, doi:10.1029/2007TC002242. TC6016.

Osmundsen, P.T. \& Redfield, T. 2011: Crustal taper and topography at passive continental margins. Terra Nova 23, 1-13.

Osmundsen, P.T., Sommaruga, A., Skilbrei, J.R. \& Olesen, O. 2002. Deep structure of the Mid Norway Rifted Margin. Norwegian Journal of Geology 82, 205-224.

Osmundsen, P.T., Henderson, I., Lauknes, T.R., Larsen, Y., Redfield, T.F. \& Dehls. J. 2009: Tectonic controls on topography and masswasting processes in Northern Norway. Geology 37, 135-138.

Osmundsen, P.T., Redfield, T.F., Anda, E., Hendriks, B.W.H., Henderson, I., Dehls, J., Lauknes, T.R., Fredin, O. \& Davidsen, B. 2010: The tectonic significance of Alpine landscapes in Norway. Journal of the Geological Society, London 167, 83-98.

Padilha, A.L., Trivedi, N.B., Vitorello, Í. \& da Costa. J.M. 1991: Geophysical constraints on tectonic models of the Taubate Basin, southeastern Brazil. Tectonophysics 196, 1-2, 157-172.

Pascal, C. \& Cloetingh, S.A.P.L. 2009: Gravitational potential stresses and stress field of passive continental margins: insights from the south-Norway shelf, Earth and Planetary Science Letters 277, 464473.

Pascal, C., Roberts, D. \& Gabrielsen, R.H. 2010: Tectonic significance of present-day stress relief phenomena in formerly glaciated regions. Journal of the Geological Society of London 167,363-371.

Peréz-Gussinyé, M. \& Reston. T. J. 2001: Rheological evolution during extension at passive, non-volcanic margins: Onset of serpentinization and development of detachments to continental breakup: Journal of Geophysical Research 106, 3961-3975.

Pérez-Gussinyé M. \& Watts, A.B. 2005: The long-term strength of Europe and its implications for plate-forming processes. Nature 436, 381-384.

Péron-Pinvidic, G. \& Manatschal, G. 2009: The final rifting evolution at deep magma-poor passive margins from Iberia-Newfoundland: a new point of view: International Journal of Earth Science (Geologische Rundschau) 98, 1581-1597.
Péron-Pinvidic, G., Manatschal, G., Dean, S.M. \& Minshull, T.A. 2008: Compressional structures on the West Iberia rifted margin: controls on their distribution. In Johnson, H., Doré, A.G., Gatliff, R.W., Holdsworth, R., Lundin, E.R. \& Ritchie, J.D. (eds.): The Nature and Origin of Compression in Passive Margins, Geological Society of London Special Publications 306, pp. 169-183.

Péron-Pinvidic, G., Manatschal, G. \& Osmundsen, P.T. 2013: Structural comparison of archetypal Atlantic rifted margins: A review of observations and concepts. Marine and Petroleum Geology 43, 21-47.

Peulvast, J.P. 1978: Le bourrelet Scandinave et les Calédonides: un essai de reconstitutiondes modalities de la morphogenèse en Norvège. Geographie Physique Quaterniare 32, 295-320.

Poudjom Djomani, Y.H., Fairhead, J.D. \& Griffin, W.L. 1999: The flexural rigidity of Fennoscandia: reflection of the tectonothermal age of the lithospheric mantle. Earth and Planetary Science Letters $174,139-154$

Pritchard, M.E., Rubin, A.M. \& Wolfe, C.J. 2007: Do flexural stresses explain the mantle fault zone beneath Kilauea volcano? International Journal of Earth Science (Geologische Rundschau) 168, 419-430.

Ramberg, .I., Bryhni, I., Nøttvedt, A. \& Rangnes, K. 2006. The making of a land - Geology of Norway. Geological Society of Norway. Trondheim. $608 \mathrm{pp}$.

Raum, T., Mjelde, R., Digranes, P., Shimamura, H., Shiobara, H., Kodaira, S., Haatvedt, G., Sørenes, N. \& Thorbjørnsen, T. 2002: Crustal structure of the southern part of the Vøring basin, midNorway margin, from wide-angle seismic and gravity data. Tectonophysics 355, 99-126.

Redfield, T.F. \& Osmundsen, P.T. 2009: The Tjellefonna fault system of Western Norway: Linking late-Caledonian extension,postCaledonian normal faulting, and Tertiary rock column uplift with the landslide-generated tsunami event of 1756 . Tectonophysics 474, 106-123.

Redfield, T.F. \& Osmundsen, P.T. 2013: The long-term topographic response of a continent adjacent to a hyperextended margin: A case study from Scandinavia. Geological Society of America Bulletin 125, 184-200.

Redfield, T.F., Torsvik, T.H., Andriessen, P.A.M. \& Gabrielsen, R.H. 2004: Mesozoic and Cenozoic tectonics of the Møre-Trøndelag Fault Complex, central Norway: constraints from new apatite fission track data. Physics and Chemistry of the Earth 10, 673-682.

Redfield, T.F., Osmundsen, P.T. \& Hendriks, B.W.H. 2005a: The role of fault reactivation and growth in the uplift of western Fennoscandia. Journal of the Geological Society of London 162,1013-1030.

Redfield, T.F., Braathen, A., Gabrielsen, R.H., Osmundsen, P.T., Torsvik, T. \& Andriessen, P.A.M. 2005b: Late Mesozoic to Early Cenozoic components of vertical separation across the Møre-Trøndelag Fault Complex, Norway. Tectonophysics 395, 233-249.

Redfield, T., Osmundsen, P.T., Gradmann, S., Bauck, M.S., Ebbing, J. \& Nasuti, A. 2011: Field excursion to Møre og Romsdal: brittle normal faults, landscapes, and tectonics: Tectonic Topography on Scandinavia's glaciated passive margin. NGU report 2011.033, 48 pp.

Reis, A.F.C., Bezerra, F.H.R., Ferreira, J.M., do Nascimento, A.F. \& Lima, C.C. 2013: Stress magnitude and orientation in the Potiguar Basin, Brazil: Implications on faulting style and reactivation. Journal of Geophysical Research: Solid Earth 118, 5550-5563.

Reusch, H. 1901: Nogle bidrag til forstaaelsen av hvorledes Norges Dale og Fjelde er blevne til. Norges Geologiske Undersøkelse, Aarbok 14, 96-102.

Reynisson, R.F. 2010: Deep structure of the mid-Norwegian margin with emphasis on the Møre margin and sub-basalt exploration using integrated gravimetric, and magnetometric models, with isostatic considerations. Ph.D. thesis. Norwegian University of Science and Technology, Trondheim, $142 \mathrm{pp}$. 
Riccomini, C. \& Assumpção, M. 1999: Quaternary tectonics in Brazil. Episodes 22, 221-225.

Riccomini, C., Peloggia, A.U.G., Saloni, J.C.L., Kohnke, M.W. \& Figueira, R.M. 1989: Neotectonic activity in the Serra do Mar rift system (southeastern Brazil): Journal of South American Earth Sciences 2, 191-197.

Richter, C.F. 1958: Elementary Seismology. Freeman, San Francisco, California, 578 pp.

Riis, F. 1996: Quantification of Cenozoic vertical movements of Scandinavia by correlation of morphological surfaces with offshore data. Global and Planetary Change 12, 331-357.

Rise, L., Ottesen, D., Berg, K. \& Lundin, E. 2005: Large-scale development of the mid-Norwegian margin during the last 3 million years. Marine and Petroleum Geology 22, 33-44.

Rohrman, M. \& van der Beek, P. 1996: Cenozoic postrift domal uplift of North Atlantic margins; an asthenospheric diapirism model. Geology 24, 901-904.

Rokoengen, K., Rise, L., Bryn, P., Frengstad, B., Gustavsen, B., Nygaard, E. \& Saettem, J. 1995: Upper Cenozoic stratigraphy on the MidNorwegian continental-shelf. Norwegian Journal of Geology 75, 88-104.

Rossavik, K. 1993: Møresokkelene: Kenozoiske stratigrafi og geologiske utvikling. Cand. scient. Thesis, Department of Geology, University of Oslo, 84 pp.

Salomon, E., Koehn, D., Passchier, C., Hackspacher, P.C. \& Glasmacher, U.A. 2014: Contrasting stress fields on correlating margins of the South Atlantic. Gondwana Research 10, doi: 10.1016/j. gr.2014.09.006.

Schermer, E. \& Redfield, T.F. 2013: Geometry of relict surfaces in Northern Norway: Implications for the extensional evolution of the NE Atlantic margin. Geophysical Research Abstracts 15, EGU20133090-3, European Geosciences Union General Assembly, 7-11 April, Vienna, Austria.

Schulte, S.M. \& Mooney, W.D. 2005: An updated global earthquake catalogue for stable continental regions: reassessing the correlation with ancient rifts. Geophysical Journal International (Geologische Rundschau) 161,707-721.

Sibson, R.H. 1994: An assessment of field evidence for "Byerlee" friction. Pageophysics 142, 645-662.

Silva, T.P. \& Mello, C.L. 2011: Neotectonic reactivations in the Rio Paraíba do Sul Shear Zone (Southeastern Brazil). Geologia USP: Série Científica 11, 95-111.

Skogseid, J. \& Eldholm, O. 1989: Vøring Plateau continental margin: Seismic Interpretation, stratigraphy, and vertical movements. Proceedings of the Ocean Drilling Program, Scientific Results 104, 993-1032.

Smelror, M., Jacobsen, T., Rise, L., Skarbø, O., Verdenius, J.G. \& Vigran, J.O. 1994: Jurassic to Cretaceous stratigraphy of shallow cores on the Møre Basin Margin, Mid-Norway. Norwegian Journal of Geology 74, 89-107.

Smelror, M., Dehls, J., Ebbing, J., Larsen, E., Lundin, E., Nordgulen, O., Osmundsen, P.T., Olesen, O., Ottesen, D., Pascal, C., Redfield, T. \& Rise, L. 2007: Towards a 4D topographic view of the Norwegian sea margin. Global and Planetary Change 58, 382-410.

Smith, W.H.F. \& Sandwell, D.T. 1997: Global seafloor topography from satellite altimetry and ship depth soundings. Science 277, 19571962.

Steer, P., Huismans, R.S., Valla, P.G., Gac, S. \& Herman, F. 2012: Bimodal Plio-Quaternary glacial erosion of fjords and low-relief surfaces in Scandinavia. Nature Geoscience 5, 635-639.

Stein, S., Cloetingh, S., Sleep, N.H. \& Wortel, R. 1989: Passive margin earthquakes, stresses and rheology. In Gregersen, S. \& Basham, P.W. (eds.): Earthquakes at North-Atlantic Passive Margins: Neotectonics and Postglacial Rebound, Kluwer Academic, Boston, MA, pp. 231259
Stephenson, R. 1984: Flexural models of continental lithosphere based on the long-term erosional decay of topography. Royal Astronomical Society Geophysical Journal 77, 385-413.

Stiberg, J.P. \& Mørk, M.E. 1990: AFFT from the western Gneiss Region: Constraints on the Cretaceous-Cenozoic uplift of southwestern Norway. Abstract, $7^{\text {th }}$ Tectonics and Structural Geology Studies Group Conference, 3-5 October, Stavanger, Norway, 67.

Stratford, W., Thybo H, Faleide, J.I., Olesen, O. \& Tryggvason, A. 2009: New Moho Map for onshore southern Norway. Geophysical Journal International (Geologische Rundschau) 178, 1755-1765.

Stuevold, L.M. 1989: Den tertiare Fennoskandisk landheving $i$ lys av vertikal bevegelser på midtnorske kontinentalmargin: En undersøkelse basert på analyse av marine geofysiske data. Cand. scient. Thesis, Department of Geology, University of Oslo, 175 pp.

Sutra, E. \& Manatschal., G. 2012: How does the continental crust thin in a hyperextended rifted margin? Insights from the Iberia margin: Geology 40, 139-142.

Sutra, E., Manatschal, G., Mohn, G. \& Unterneher, P. 2013: Quantification and restoration of extensional deformation along the Western Iberia and Newfoundland rifted margins. Geochemistry, Geophysics, Geosystems 14, 2575-2597.

Svenningsen, N., Balling N., Jacobsen, B.H., Kind, R., Wylegalla K., Schweitzer, J. \& Svenningsen, L. 2007: Crustal root beneath the highlands of southern Norway resolved by teleseismic receiver functions. Geophysical Journal International (Geologische Rundschau) 170, 11-29.

Sykes, L. 1978: Intraplate seismicity, reactivation of pre-existing zones of weakness, alkaline magmatism, and other tectonism postdating continental fragmentation, Reviews of Geophysics 16, 621-688.

Sømme, T., Martinsen, O.J. \& Thurmond, J.B. 2009: Reconstructing morphological and depositional characteristics in subsurface sedimentary systems: An example from the Maastrichtian-Danian Ormen Lange system, Møre Basin, Norwegian Sea. American Association of Petroleum Geologists Bulletin 93, 1-31.

Sømme, T., Martinsen, O.J. \& Lunt, I. 2013a: Linking offshore stratigraphy to onshore paleotopography: The Late JurassicPaleocene evolution of the south Norwegian margin. Geological Society of America Bulletin 125, 1164-1186.

Sømme, T.O., Helland-Hansen, W. \& Martinsen, O.J. 2013b: Quantitative aspects of stratigraphic onshore offshore relationships along the western margin of southern Norway: implications for Late Mesozoic and Cenozoic topographic evolution. Norwegian Journal of Geology 93, 261-276.

Tarr, A.C., Villaseñor, A., Furlong, K.P., Rhea, S. \& Benz, H.M. 2010: Seismicity of the Earth 1900-2007 Scientific Investigations Map 3064, scale 1:25,000,000, U.S. Geological Survey.

Tesauro, M., Kaban, M.K. \& Cloetingh, S.A.P.L. 2008: EuCRUST-07: a new reference model for the European crust. Geophysical Research Letters 35, L05313, doi: 10.1029/2007GL032244.5.

Thompson, G.A. \& Parsons, T. 2009: Can footwall unloading explain late Cenozoic uplift of the Sierra Nevada crest? International Geology Review 51, 986-993.

Torgersen, E., Viola, G., Zwingmann, H. \& Harris, C. 2014: Structural and temporal evolution of a reactivated brittle-ductile fault - Part II: Timing of fault initiation and reactivation by $\mathrm{K}-\mathrm{Ar}$ dating of synkinematic illite/muscovite. Earth and Planetary Science Letters 407, 221-233.

Torske, T. 1972: Tertiary oblique uplift of Western Fennoscandia; crustal warping in connection with rifting and break-up of the Laurasian continent. Norges Geologisk undersøkelse Bulletin 273, $43-48$.

Turcotte, D. \& Schubert, G. 1982. Geodynamics: Applications of continuum physics to geological problems. John Wiley \& Sons, New York, $450 \mathrm{pp}$.

Turcotte, D.L., NcAdoo, D.C. \& Caldwell, J.C. 1978: An elastic-perfectly plastic analysis of the bending of the lithosphere at a trench. Tectonophysics 47, 193-205. 
Uski, M., Hyvönen, T. Korja, A. \& Airo, M. 2003: Focal mechanisms of three earthquakes in Finland and their relation to surface faults. Tectonophysics 363, 141-157.

Vening Meinesz, F. 1950: Les grabens africains, résultat de compression ou de tension dans la Cröute terrestre? Institut Royal Colonial Belge Bulletin des Séances 21,539-552.

Vestøl, O. 2006: Determination of postglacial land uplift in Fennoscandia from leveling, tide-gauges and continuous GPS stations using least squares collocation. Journal of Geodesy 80, 248258.

Walcott, R. 1972: Gravity, Flexure, and the Growth of Sedimentary Basins at a Continental Edge. Geological Society of America Bulletin 83, 1845-1848.

Watts, A.B. 2001: Isostasy and flexure of the lithosphere. Cambridge University Press, Cambridge, $458 \mathrm{pp}$.

Watts, A.B., Rodger, M., Peirce, C., Greenroyd, C.J. \& Hobbs, R. 2009: Seismic structure, gravity anomalies, and flexure of the Amazon continental margin, NE Brazil. Journal of Geophysical Research 114, doi: 101029/2008JB006259.

Weissel, J.K. \& Karner, G.D. 1989: Flexural uplift of rift flanks due to mechanical unloading of the lithosphere during extension. Journal of Geophysical Research 94, 13919-13950.

Wells, D.L. \& Coppersmith, K.J. 1994: New empirical relationships among magnitude, rupture length, rupture width, rupture area, and surface displacement. Bulletin of the Seismological Society of America 84, 974-1002.

Wu, P. \& Hasagawa, H.S. 1996: Induced stresses and fault potential in eastern Canada due to a disc load: a preliminary analysis. Geophysical Journal International (Geologische Rundschau) 125, 415-430.

Zalán, P.V. \& Oliveira, J.A.B. 2005: Origin and structural evolution of the Cenozoic rift system of Southeastern Brasil: Boletim Geociiencias de Petrobras, Rio de Janeiro 13, 269-300.

Zalán, P.V., Severino, M.C.G., Rigoti, C., Magnavita, L.P., Oliveira, J.A.B. \& Viana, A.R. 2011: An entirely new 3D-view of the crustal and mantle structure of a ruptured South Atlantic passive margin - Santos, Campos and Espírito Santo Basins, Brazil: American Association of Petroleum Geologists Annual Convention and Exhibition Abstracts Volume CD-ROM, Paper 986156 (Expanded Abstract), 10-13 April, Houston, Texas.

Ziegler, P.A. \& Cloething, S. 2004: Dynamic processes controlling evolution of rifted basins. Earth Science Reviews 64, 1-50.

Zoback, M.L. 1992: Stress field constraints on intraplate seismicity in Eastern North America. Journal of Geophysical Research 97, 1176111782.

Zoback, M.D. 2007: Reservoir Geomechanics. Cambridge University Press, Cambridge, 448 pp. 